\title{
PEMULIHAN EKONOMI NASIONAL PADA MASA PANDEMI COVID-19: ANALISIS PRODUKTIVITAS TENAGA KERJA SEKTOR PERTANIAN
}

\author{
M. Zainul Abidin \\ Kementerian Keuangan, Jakarta
}

Alamat Korespondensi:

abidinmz@gmail.com

\begin{abstract}
This study aims to determine the impact of the Covid-19 pandemic on labor productivity in the agricultural and the National Economic Recovery (PEN) Program to support labor productivity in the agricultural sector. This research method is descriptive qualitative using secondary data. The results showed that the Covid-19 pandemic had an impact on labor productivity in the agricultural sector. The pandemic increases health risks, disrupts agricultural production and marketing, increases the burden of health expenditures, and reduces access to education and training. The PEN program supports the productivity of the agricultural sector workforce by providing assistance and developing the capacity of the farm workforce using the distribution of social assistance (bansos) and additional pre-employment card allocations. The social assistance and capacity-building program for the agricultural workforce enabled the agricultural workforce to continue working and being productive, thus supporting the sustainable development of the farming sector.
\end{abstract}

Keywords:

Agricultural, Covid-19, Labor Productivity, National Economic Recovery

\begin{abstract}
ABSTRAK
Penelitian ini bertujuan untuk mengetahui dampak pandemi Covid-19 terhadap produktivitas tenaga kerja sektor pertanian dan program PEN yang dapat mendukung produktivitas tenaga kerja sektor pertanian. Metode penelitian ini adalah kualitatif deskriptif menggunakan data sekunder. Hasil penelitian menunjukkan bahwa pandemi Covid-19 berdampak negatif terhadap produktivitas tenaga kerja sektor pertanian. Pandemi tersebut meningkatkan risiko kesehatan, menimbulkan gangguan proses produksi dan pemasaran produk pertanian, meningkatkan beban pengeluaran kesehatan serta mengurangi akses pendidikan dan pelatihan yang dapat menurunkan produktivitas tenaga kerja sektor pertanian. Program PEN mendukung produktivitas tenaga kerja sektor pertanian melalui pemberian bantuan dan pengembangan kapasitas tenaga kerja sektor pertanian menggunakan penyaluran bantuan sosial (bansos) dan tambahan alokasi kartu prakerja. Bantuan sosial dan program pengembangan kapasitas tenaga kerja sektor pertanian tersebut meringankan beban dan memungkinkan tenaga kerja sektor pertanian tetap bekerja dan produktif sehingga dapat mendukung perkembangan sektor pertanian yang berkelanjutan.
\end{abstract}

Kata Kunci:

Covid-19, Pemulihan Ekonomi Nasional, Produktivitas Tenaga Kerja, Sektor Pertanian

KLASIFIKASI JEL:

E62, H20, H50

CARA MENGUTIP:

Abidin, M. Z., (2021). Pemulihan ekonomi nasional pada masa pandemi covid-19: analisis produktivitas tenaga kerja sektor pertanian. Indonesian Treasury Review: Jurnal Perbendaharaan, Keuangan Negara dan Kebijakan Publik, 6(2), 117-138. 


\section{PENDAHULUAN}

Sektor pertanian memiliki peran penting dalam perekonomian Indonesia. Sektor pertanian memberikan kontribusi terhadap Produk Domestik Bruto (PDB) setelah industri manufaktur dan perdagangan (Grafik 1). Pada tahun 2019, nilai tambah dan tingkat produksi Sektor Pertanian, Kehutanan dan Perikanan mencapai Rp1.354 triliun atau 12,4 persen dari PDB nasional (BPS, 2020).

Grafik 1. Kontribusi Sektor Ekonomi Terhadap PDB Tahun 2014 - 2019 (persen)

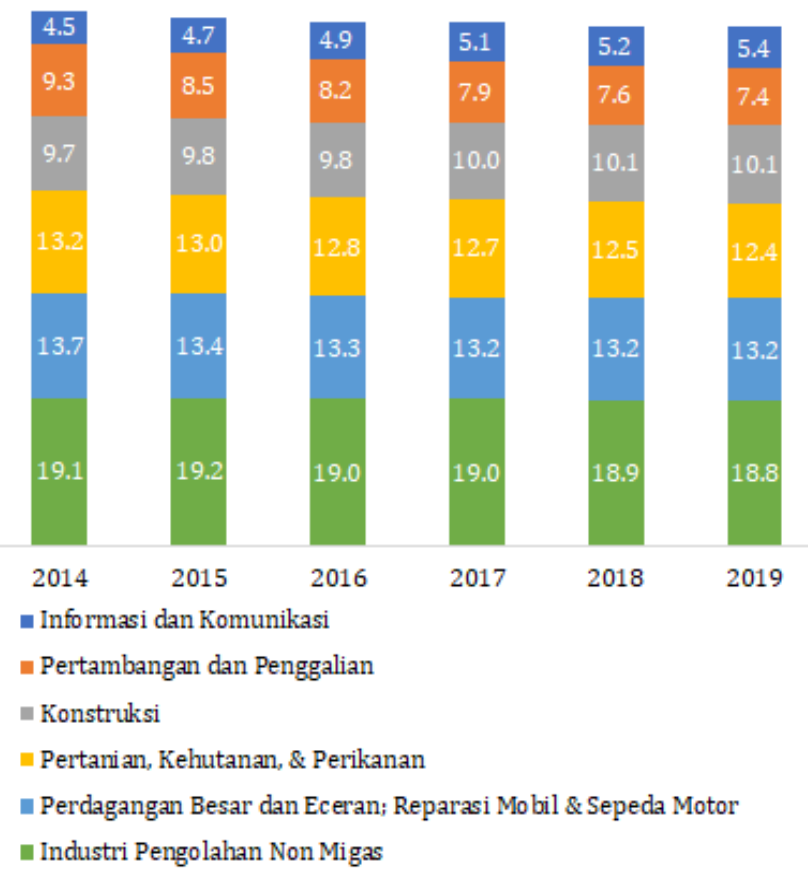

Sumber: BPS (2020)

Sektor pertanian mendukung ketahanan pangan dan meningkatkan kesejahteraan masyarakat. Di sisi lain, kesejahteraan para petani memegang peran penting dalam menjaga dan meningkatkan produksi pertanian. Sektor pertanian yang maju dapat mendorong pertumbuhan ekonomi yang lebih cepat dan mengentaskan kemiskinan.

Sektor pertanian menyerap tenaga kerja yang cukup besar, terutama di daerah perdesaan. Pada Agustus 2020, jumlah angkatan kerja sebanyak 137,91 juta orang. Sektor pertanian menyerap angkatan kerja terbesar, yaitu sebesar 29,04 persen, diikuti sektor perdagangan dan manufaktur masing-masing sebesar 18,63 persen dan 14,09 persen (BPS, 2020a).

Terdapat sejumlah faktor yang dapat menghambat perkembangan sektor pertanian Indonesia. Selain ketersediaan lahan, tingkat produksi pertanian belum optimal (Dahiri \& Fitri, 2020). Hal itu terkait dengan kemampuan pelaku sektoral yang berdampak pada tingkat inovasi dan

\section{PENERAPAN DALAM PRAKTIK}

- Pandemi Covid-19 berdampak negatif terhadap produktivitas tenaga kerja sektor pertanian.

- Program Pemulihan Ekonomi Nasional dapat mendukung produktivitas tenaga kerja sektor pertanian.

- Dalam jangka pendek, penyaluran bantuan sosial bagi kelompok kurang mampu dapat diprioritaskan guna mempertahankan produktivitas tenaga kerja di sektor pertanian.

- Dalam jangka panjang, tambahan alokasi kartu prakerja mendukung produktivitas tenaga kerja pertanian melalui peningkatan pengetahuan dan keterampilan.

penguasaan teknologi yang relatif rendah. Rendahnya kemampuan tersebut menyebabkan produksi sektor pertanian belum optimal. Upaya peningkatan kemampuan pelaku sektor pertanian diperlukan guna meningkatkan laju pertumbuhan ekonomi nasional.

Pandemi Covid-19 merupakan pandemi yang berdampak global dengan tingkat penyebaran yang tinggi dan mempengaruhi berbagai aspek kehidupan masyarakat. Selain tidak terduga, penyebaran Covid-19 sangat cepat dan menimbulkan dampak yang meluas antar wilayah sehingga mengganggu keberlangsungan berbagai sektor. Pandemi tersebut mengakibatkan terjadinya situasi krisis di banyak negara/daerah.

Pandemi COVID-19 sangat memengaruhi kehidupan manusia. Kehidupan sehari-hari menjadi sulit, terutama bagi mereka yang tinggal di wilayah yang terkena pembatasan sosial (Fry-Bowers, 2020; Qarnain et al., 2020). Kerugian ekonomi dan nonekonomi dialami oleh semua sektor (Chakraborty dan Maity, 2020; Lal et al., 2020; Mukiibi, 2020). Kondisi ekonomi sejak pandemi yang tidak menentu mengakibatkan banyak perusahaan hanya dapat bertahan untuk waktu yang singkat. Untuk menekan biaya, banyak pengusaha mengurangi jumlah pekerja (Fry-Bowers, 2020). Pembatasan aktivitas sosial, isolasi diri, dan larangan bepergian telah menyebabkan banyak penduduk kehilangan pekerjaan.

Jumlah pekerja yang kehilangan pekerjaan menyebabkan ancaman terhadap kehidupan sosial. Di samping itu, pandemi Covid-19 menciptakan tantangan terhadap isu sosial ekonomi (Nicola et al., 2020), input rendah untuk produktivitas pertanian, dampak sosial pandemi (Ashraf, 2020), dan kerentanan sosial ekonomi (Mikolai et al., 2020).

Dampak Covid-19 terhadap aspek ekonomi cukup masif. Tindakan karantina di wilayah darat, perairan, dan udara dalam skala lokal maupun internasional menyebabkan pertumbuhan ekonomi 
yang stagnan di semua sektor. Situasi ini berdampak pada rendahnya produktivitas karena rendahnya permintaan dan rendahnya penggunaan transportasi terutama untuk keperluan impor dan ekspor. Hal ini mengakibatkan tingkat pengangguran yang tinggi. Pertumbuhan ekonomi global semakin memburuk selama penyebaran wabah Covid-19 (Ozili et al., 2020). Rendahnya produktivitas tenaga kerja juga terjadi di Indonesia. Jumlah pengangguran juga tinggi dan penggunaan transportasi rendah. Hal-hal tersebut sangat mempengaruhi lambatnya pertumbuhan ekonomi di Indonesia (Tabel 1). Pertumbuhaozin ekonomi tahun 2020 sangat rendah dibandingkan dengan tahun sebelumnya (Sohrabi, 2020).

Sejak diumumkan Maret 2020, Covid-19 menyebar secara luas di Indonesia. Pemerintah Indonesia merespon pandemi Covid-19 dengan menerbitkan berbagai regulasi guna mengurangi risiko penularan melalui pembatasan aktivitas masyarakat secara berkelompok. Namun, kebijakan pembatasan sosial menciptakan gejolak negatif, seperti terhambatnya aksesibilitas dan mobilitas tenaga kerja yang berdampak terhadap aktivitas ekonomi, pengangguran, dan penurunan produktivitas. Pandemi Covid-19 berdampak secara sosial dan ekonomi. Pandemi tersebut mempengaruhi berbagai bidang, antara lain sistem kesehatan, ketenagakerjaan dan aksesibilitas masyarakat. Hasil survei dampak Covid-19 menunjukkan bahwa 6 dari 10 masyarakat telah dirumahkan (BPS, 2020a). Dampak Covid-19 diperkirakan menambah jumlah pengangguran sebanyak 3,78 juta orang. Tenaga kerja yang terdampak Covid-19 sebagian besar bekerja di sektor yang rentan seperti UMKM, transportasi dan akomodasi (BPS, 2020b).

Tabel 1. Proyeksi Pertumbuhan Ekonomi dan Potensi Dampak Sosial Covid-19 Tahun 2020

\begin{tabular}{cccc}
\hline Skenario & $\begin{array}{c}\text { Proyeksi } \\
\text { Pertumbuhan } \\
\text { Ekonomi } \\
\text { (persen) }\end{array}$ & $\begin{array}{c}\text { Potensi Dampak Sosial } \\
\text { Penurunan Pertumbuhan } \\
\text { Ekonomi (juta orang) }\end{array}$ \\
\hline Pengangguran Kemiskinan \\
\hline $\begin{array}{c}\text { Sangat } \\
\text { berat }\end{array}$ & 2,3 & $+2,92$ & $+1,89$ \\
\hline \multicolumn{3}{c}{ Sumber: Kementerian Keuangan (2020a) }
\end{tabular}

Pandemi Covid-19 menjadi tantangan bagi Indonesia karena mempengaruhi pertumbuhan ekonomi dan produktivitas tenaga kerja. Jumlah pekerja yang terdampak, terkena Pemutusan Hubungan Kerja (PHK) dan dirumahkan sebanyak 3,05 juta orang. Hasil survei menyebutkan bahwa pekerja yang di-PHK akibat perusahaan/tempat usaha ditutup sebesar 2,52 persen dan 18,34 persen masih bekerja, tetapi dirumahkan (BPS, 2020b).
Dalam periode Agustus 2019 sampai dengan Agustus 2020, jumlah angkatan yang menganggur (pengangguran) telah bertambah sebanyak 2,67 juta orang atau meningkat sebesar 37,61 persen. Di samping itu, pandemi Covid-19 menyebabkan penurunan rata-rata upah buruh dari Rp2,91 juta menjadi Rp2,76 juta atau minus 5,20 persen (BPS, 2020c).

Tantangan dampak Covid-19 muncul dari sisi kualitas sumber daya manusia (SDM) karena pandemi mengakibatkan jumlah pengangguran bertambah, khususnya penduduk usia produktif. Di sisi lain, keberadaan penduduk usia produktif dapat menjadi potensi percepatan pertumbuhan sektor pertanian. Potensi tersebut memerlukan intervensi pemerintah melalui investasi SDM yang berkualitas.

Data Kementerian Pertanian tahun 2020 menyebutkan bahwa jumlah tenaga kerja Sektor Pertanian sebanyak 35 juta orang (Kementerian Pertanian, 2020a). Sebagian besar pekerja pertanian bekerja di subsektor tanaman pangan sebanyak 17,22 juta jiwa, perkebunan sebanyak 10,31 juta orang, peternakan sebanyak 4,30 juta orang, dan hortikultura sebanyak 3,17 juta orang (Grafik 2). Tenaga kerja sektor pertanian didominasi wanita sebanyak 21,52 juta jiwa $(61,48$ persen), sementara pria sebanyak 13,48 juta jiwa (38,52 persen)

\section{Grafik 2. Jumlah Tenaga Kerja Sektor Pertanian} Berdasarkan Subsektor, Februari 2020

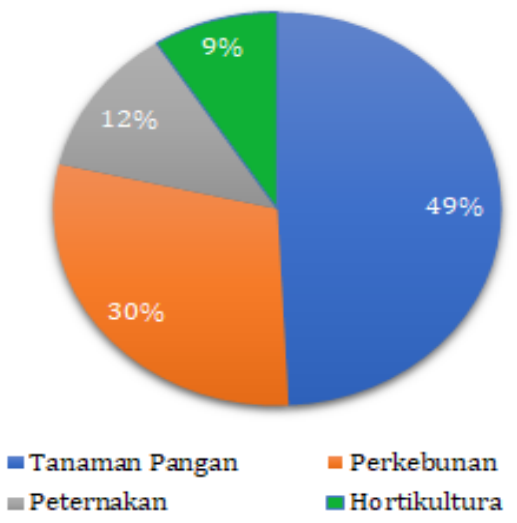

Sumber: Kementerian Pertanian (2020a)

Sebagian besar pendidikan tenaga kerja sektor pertanian berada pada tingkat pendidikan dasar. Tingkat pendidikan yang relatif rendah mengakibatkan produktivitas yang rendah. Data Kementerian Pertanian tahun 2020 menunjukkan bahwa sebagian besar tenaga kerja sektor pertanian berpendidikan SD, yaitu 84,22 persen, sementara yang berpedidikan tinggi hanya sebesar 1,76 persen (Kementerian Pertanian, 2020a).

Di kawasan ASEAN, produktivitas tenaga kerja sektor pertanian Indonesia masih di bawah Malaysia dan Thailand (Utomo \& Baskoro, 2019). Hasil Survei Pertanian Antar Sensus (SUTAS) 2018 
menyebutkan bahwa petani utama di Indonesia didominasi penduduk berusia 45-64 tahun, yaitu sebesar 50 persen lebih. Sementara itu, petani berusia 65 tahun ke atas mencapai 13 persen. Petani yang berusia kurang dari 45 tahun hanya sekitar 35 persen (BPS, 2019). Penguasaan terknologi merupakan hal penting untuk mendongkrak produktivitas. Namun, faktor pendidikan dan usia angkatan kerja pertanian kurang mendukung penyerapan/adaptasi teknologi.

Situasi yang dialami oleh masyarakat akibat pandemi Covid-19 menyebabkan dampak ekonomi. Dampak ekonomi tersebut berpotensi dialami oleh para petani sehingga dapat menurunkan produksi pertanian. Hal itu dapat menyebabkan kerugian ekonomi dan menurunkan kesejahteraan para petani. Salah satu upaya pemulihan ekonomi pasca bencana yang dapat ditempuh dilakukan melalui penguatan perekonomian petani. Upaya tersebut ditempuh melalui intervensi pemerintah untuk memperkuat kompetensi sumber daya manusia sektor pertanian.

Pertanian telah menjadi salah satu sektor yang paling terkena dampak pandemi (Wang et al., 2020). Sektor pertanian berperan penting untuk ketahanan pangan, yang berarti pandemi dapat mempengaruhi ketahanan pangan. Namun, hambatan produksi pertanian merupakan masalah bagi banyak negara, terutama negara berkembang. Pandemi telah memperbesar masalah di sektor pertanian (Thow et al., 2019).

Pada tahun 2020, Sektor Pertanian tumbuh 1,75 persen (BPS, 2020d). Hal itu menunjukkan bahwa sektor pertanian mampu menunjukkan daya tahan yang relatif baik saat pandemi Covid-19. Pertumbuhan sektor pertanian disebabkan adanya peningkatan luas panen dan produksi padi, jagung, ubi kayu serta cuaca yang mendukung, tumbuhnya permintaan buah-buahan dan sayuran selama pandemi COVID-19 serta kenaikan harga komoditas kelapa sawit (Sekretariat Kabinet, 2021). Di sisi lain, dampak pandemi Covid-19 dapat meluas sehingga meningkatkan risiko kesehatan tenaga kerja dan mengancam produktivitas.

Pada 31 Maret 2020, Pemerintah menerbitkan Peraturan Pemerintah Pengganti Undang-Undang Nomor 1 Tahun 2020 tentang Kebijakan Keuangan Negara dan Stabilitas Sistem Keuangan untuk Penanganan Pandemi Corona Virus Disease 2019 (Covid-19) dan/atau Dalam Rangka Menghadapi Ancaman yang Membahayakan Perekonomian Nasional dan/atau Stabilitas Sistem Keuangan. Perdasarkan Perpu 1/2020, Pemerintah menetapkan Perpres 54/2020 yang mengatur tentang perubahan postur APBN pada tahap pertama. Pada 16 Mei 2020, Perpu 1/2020 disetujui DPR menjadi Undang-Undang Nomor 2 Tahun 2020 tentang Penetapan Peraturan Pemerintah
Pengganti Undang-Undang Nomor 1

Tahun 2020 tentang Kebijakan Keuangan Negara dan Stabilitas Sistem Keuangan untuk Penanganan Pandemi Corona Virus Disease 2019 (Covid-19) dan/atau Dalam Rangka Menghadapi Ancaman yang Membahayakan Perekonomian Nasional dan/atau Stabilitas Sistem Keuangan. Penetapan UU 1/2020 diikuti dengan penetapan Perpres 72/2020 yang mengatur perubahan postur APBN tahap kedua. Perubahan postur APBN tersebut merupakan realokasi belanja APBN 2020 dalam UU 20/2019 tentang APBN 2020 guna melaksanakan tertib anggaran dalam rangka pemulihan ekonomi nasional pasca pandemi Covid-19.

Program Pemulihan Ekonomi Nasional (PEN) bertujuan melindungi, mempertahankan dan meningkatkan kemampuan para pelaku usaha dalam menjalankan usahanya selama pandemi Covid-19. Di samping itu, program PEN membantu meningkatkan daya beli masyarakat serta memulihkan perekonomian Indonesia secara keseluruhan. Program PEN menyasar rumah tangga masyarakat yang paling rentan dan sektor usaha (UMKM, Korporasi, dan BUMN). Dengan adanya program PEN diharapkan roda perekonomian dapat berputar dan mendorong pertumbuhan ekonomi.

UU 1/2020 menjadi dasar dalam pengambilan program PEN. Selanjutnya, dukungan APBN diperlukan untuk mendukung bidang kesehatan, penanganan dampak sosial dan pemulihan ekonomi. Penanganan dampak sosial dilaksanakan melalui program perlindungan sosial dan penyelamatan perekonomian nasional dilaksanakan melalui pemberian insentif fiskal, dukungan perkreditan dan aspek moneter.

Dampak pandemi terhadap ekonomi telah dikaji secara luas. Pandemi menyebabkan produktivitas pertanian berkurang di negaranegara berkembang (Mphande, 2016). Gatiso menyebutkan bahwa penyebaran virus Ebola telah menurunkan pendapatan rumah tangga, mengancam ketahanan pangan, dan penurunan kehidupan sosial di Liberia (Gatiso et al,. 2018). Sementara itu, penelitian terhadap dampak penyebaran Human Immunodeficiency Virus (HIV) di Afrika menunjukkan bahwa penyebaran tersebut telah mengurangi penduduk usia muda untuk memperoleh/mengakses pendapatan/pekerjaan (Ansell et al., 2016). Sementara itu, terdapat berbagai jenis program dan kebijakan yang dianggap efektif dalam mendukung sektor usaha dan pemulihan ekonomi (Alesales Webb et al., 2002) Sejumlah penelitian telah menggambarkan dampak negatif pandemi Covid-19 terhadap ekonomi. Namun, dampak pandemi Covid-19 terhadap produktivitas pertanian di Indonesia dan kebijakan mengatasi dampak negatif pandemi Covid-19 terhadap produktivitas pertanian di 
Indonesia belum dibahas/diteliti secara khusus. Berbagai teori dan penelitian sebelumnya telah menjelaskan dampak krisis/pandemi terhadap ekonomi, tetapi belum secara khusus terhadap kondisi krisis yang disebabkan oleh bencana pandemi Covid-19 sehingga hal itu menarik untuk dikaji guna melengkapi pengetahuan dampak pandemi Covid-19 terhadap produktivitas tenaga kerja sektor pertanian Indonesia. Pemahaman terhadap dampak negatif pandemi Covid-19 terhadap sektor pertanian berguna dalam mengembangkan konsep daya tahan sektor pertanian atas pandemi Covid-19 dan formulasi kebijakan pemerintah dalam menjaga keberlanjutan sektor pertanian selama dan setelah pandemi. Oleh karena itu, penelitian ini membahas dampak krisis pandemi Covid-19 terhadap produktivitas tenaga kerja sektor pertanian di Indonesia. Penelitian ini juga bertujuan untuk menganalisis kebijakan untuk mengatasi dampak negatif Covid-19 terhadap produktivitas sektor pertanian di Indonesia dari berbagai literatur/data yang terkait. Berbagai data dan informasi yang dikumpulkan disandingkan dengan kajian/studi literatur untuk memperoleh suatu tinjauan yang relevan dengan produktivitas dan daya tahan sektor pertanian.

Upaya untuk mengurangi risiko dampak pandemi telah dilakukan pemerintah melalui program PEN. Namun, program PEN perlu ditinjau relevansinya terhadap sektor pertanian. Program PEN yang mendukung produktivitas tenaga kerja sektor pertanian perlu dilakukan agar produksi dan kesejahteraan tenaga kerja sektor pertanian dapat dipertahankan dan ditingkatkan. Berdasarkan latar belakang yang telah dijelaskan, penelitian ini bertujuan untuk mengetahui dampak pandemi Covid-19 terhadap produktivitas tenaga kerja sektor pertanian dan program PEN yang dapat mendukung produktivitas tenaga kerja sektor pertanian.

\section{STUDI LITERATUR}

\section{Pemulihan Ekonomi Pasca Bencana}

Undang-undang Nomor 24 Tahun 2007 Tentang Penanggulangan Bencana menyebutkan definisi bencana sebagai peristiwa atau rangkaian peristiwa yang mengancam dan mengganggu kehidupan dan penghidupan masyarakat sehingga mengakibatkan timbulnya korban jiwa manusia, kerusakan lingkungan, kerugian harta benda, dan dampak psikologis. Definisi bencana tersebut memiliki tiga aspek, yaitu: 1) peristiwa yang menimbulkan gangguan atau ancaman, 2) peristiwa atau gangguan tersebut membahayakan manusia dan lingkungan, 3) mengakibatkan korban dan tidak adanya kemampuan masyarakat untuk mengatasi gangguan tersebut.
Bencana mengakibatkan terjadinya kerentanan, yaitu keadaan penurunan ketahanan masyarakat dalam mengatasi gangguan yang membahayakan kehidupan. Kerentanan terjadi akibat pengaruh eksternal yang mengancam kehidupan, mata pencaharian, sumber daya alam, infrastruktur, produktivitas ekonomi, dan kesejahteraan (Abast, Moniaga \& Gosal, 2016). Kerentanan dalam pengertian ini adalah ukuran kapasitas rumah tangga untuk mengantisipasi, mengatasi, bertahan, dan memulihkan diri dari dampak bencana (De Silva \& Kawasaki, 2018).

Kerentanan ekonomi menyertai terjadinya suatu bencana. Kerentanan ekonomi menggambarkan adanya gangguan aktivitas ekonomi atau adanya kerugian yang timbul dari ancaman bahaya (Sauda, Nugraha, \& Hani'ah, 2019). Tingkat kerentanan terhadap ancaman bahaya dipengaruhi oleh status atau kemampuan ekonomi suatu individu atau masyarakat.

Dalam pembahasan terkait ekonomi, konsep kerentanan umumnya mencakup empat fokus/penekanan selain bencana itu sendiri, yaitu kemiskinan, ketahanan pangan, kerentanan aset, dan pembangunan berkelanjutan. Seringkali, kerentanan dianalisis dalam studi tentang dinamika kemiskinan, dengan fokus pada risiko jatuh ke dalam kemiskinan atau kemiskinan yang lebih dalam (Noy \& Yonson, 2018).

Terdapat korelasi positif antara kerusakan akibat bencana, kemiskinan, dan kerentanan. Kerentanan dapat ditentukan oleh faktor ekonomi suatu masyarakat terhadap dampak bencana. Masyarakat kategori miskin atau kurang mampu lebih rentan terhadap kerentanan ekonomi karena memiliki kemampuan finansial yang relatif terbatas dalam upaya pencegahan atau mitigasi bencana. Semakin rendah tingkat ekonomi, tingkat kerentanan dalam menghadapi bencana akan semakin tinggi (Asrul, Indra, \& Ismail, 2014). Rumah tangga miskin seringkali hanya bergantung pada pertanian untuk mencari nafkah sehingga lebih rentan terhadap dampak bencana. Bencana memiliki dampak ekonomi yang serupa pada masyarakat. Namun, hubungan antara kemiskinan dan kerusakan finansial akibat bencana (dan kerentanan) lebih kompleks. Kerugian ekonomi rata-rata secara absolut jauh lebih tinggi untuk rumah tangga kaya. Di sisi lain, kapasitas penanggulangan rumah tangga kaya juga lebih besar, yang tercermin dari fakta bahwa kerugian akibat bencana relatif terhadap pendapatan ratarata tahunan secara signifikan lebih rendah untuk rumah tangga kaya. Sebaliknya, kerugian finansial akibat bencana, secara relatif, jauh lebih tinggi untuk rumah tangga miskin bencana alam. Bagi rumah tangga miskin yang hanya bergantung pada pertanian untuk mencari nafkah, dan memiliki 
sedikit tanah, terjadinya bencana alam dapat meruntuhkan sendi-sendi kehidupan utama. Seringkali warga miskin membutuhkan waktu lama untuk pulih dari bencana alam, dan dapat menimbulkan konflik sosial ekonomi (De Silva \& Kawasaki, 2018).

Dampak sosial ekonomi dari suatu bencana terhadap rumah tangga berupa kerugian ekonomi, termasuk kerusakan harta benda yang digunakan sebagai mata pencaharian (Tabel 2). Harta benda dan mata pencaharian yang telah rusak dapat menurunkan kualitas hidup dan produktivitas ekonomi. Adapun sumbangan atau pemberian kompensasi atas kerugian finansial dapat menggantikan aset lain yang hilang/rusak. Di samping itu, terdapat pengaruh tidak langsung, terutama aliran dana antar unit sosial masyarakat yang disebabkan terganggunya arus produksi, jasa, input ekonomi dan dukungan infrastruktur. Penutupan usaha setelah terjadi bencana dapat meningkatkan jumlah pengangguran karena korban sulit mempertahankan atau mendapatkan pekerjaan (Arouri, Nguyen, \& Youssef, 2015).

Tabel 2. Dampak Bencana Terhadap Sektor Usaha dan Ekonomi

\begin{tabular}{|c|c|}
\hline $\begin{array}{c}\text { Kerugian Sektor } \\
\text { Usaha/Bisnis }\end{array}$ & Kerugian Ekonomi \\
\hline $\begin{array}{l}\text { 1.Berkurangnya jumlah } \\
\text { produksi pertanian. } \\
\text { 2.Berkurangnya jumlah } \\
\text { pendapatan dari hasil } \\
\text { pertanian. } \\
\text { 3.Bertambahnya beban } \\
\text { pengeluaran untuk } \\
\text { membeli perlengkapan } \\
\text { kesehatan dan } \\
\text { suplemen daya tahan } \\
\text { tubuh. } \\
\text { 4.Berkurangnya } \\
\text { kesempatan kerja bagi } \\
\text { anggota keluarga. } \\
\text { 5.Adanya ketergantungan } \\
\text { terhadap bantuan pihak } \\
\text { lain. }\end{array}$ & $\begin{array}{l}\text { 1.Berkurangnya tenaga kerja. } \\
\text { 2.Berkurangnya } \\
\text { kesempatan/lapangan } \\
\text { kerja bagi angkatan kerja } \\
\text { muda } \\
\text { 3. Berkurangnya tenaga kerja } \\
\text { yang ahli/ terampil. } \\
\text { 4. Berkurangnya regenerasi } \\
\text { angkatan kerja pertanian. } \\
\text { 5.Adanya pengaruh terhadap } \\
\text { pengetahuan tenaga kerja } \\
\text { karena berkurangnya } \\
\text { penyuluhan/ pendidikan. } \\
\text { 6.Tingkat keterampilan } \\
\text { tenaga kerja yang menurun } \\
\text { akibat angkatan kerja muda } \\
\text { terpaksa memasuki jenis } \\
\text { pekerjaan yang tidak } \\
\text { terampil dan } \\
\text { menghilangkan } \\
\text { kesempatan penduduk usia } \\
\text { muda untuk belajar. }\end{array}$ \\
\hline
\end{tabular}

Sumber: Arouri, Nguyen, \& Youssef (2015)

Di sektor pertanian, dampak pandemi dapat menurunkan/mengurangi ketersediaan tenaga kerja dan produktivitas tenaga kerja. Akibat jangka panjang, tanpa respon dan penanganan yang tepat, produksi pertanian akan turun. Hal ini pernah dialami Ghana saat wabah Ebola terjadi pada tahun 2014 dengan kerugian produksi kopi dan beras yang menurun hingga 50 persen (Lucas, 2020).
Bencana adalah fenomena yang terjadi karena komponen pemicu, bahaya dan kerentanan yang bekerja sama secara sistematis sehingga menimbulkan risiko bagi masyarakat. Oleh karena itu perlu dilakukan serangkaian upaya untuk mengurangi risiko bencana, baik melalui kesadaran pembangunan fisik dan peningkatan kemampuan menghadapi ancaman bencana. Upaya tersebut dinamakan mitigasi bencana, yang terdiri dari mitigasi struktural dan non struktural. Mitigasi struktural meliputi pembangunan infrastruktur untuk mendorong minimisasi dampak. Mitigasi non struktural mencakup penyusunan regulasi, penataan ruang, pelatihan dan pemberdayaan masyarakat serta pemerintah daerah (Mononimbar, 2019).

Kegiatan mitigasi bencana memiliki kaitan dengan proses perencanaan pembangunan (Faturahman, 2018). Pemulihan merupakan awal dari upaya rekonstruksi dan umumnya merupakan bagian dari pembangunan. Restorasi mendorong terjadinya kegiatan sosial, ekonomi dan budaya dengan tujuan utama membangkitkan partisipasi masyarakat dalam semua aspek kehidupan. Aspek pemulihan mencakup pemulihan/normalisasi semua aspek pelayanan publik, termasuk pemulihan sosial ekonomi jangka menengah hingga jangka panjang.

Di tingkat rumah tangga, sumber daya individu yang terkena dampak bencana dan perlu dipulihkan meliputi aspek kesehatan, kemampuan jasmani, kesehatan mental, pendidikan, pengetahuan, dan keterampilan menghadapi bencana. Kesehatan, pendidikan, pengetahuan, dan kemampuan fisik seseorang berdampak pada proses pemulihan yang diperlukan, seperti kemampuan untuk memanfaatkan peluang, mengakses sumber daya, menghadapi berbagai tantangan pascabencana, dan mempersiapkan diri menghadapi bencana di masa depan (Morganstein \& Ursano, 2020).

Kebijakan untuk memulihkan dampak kondisi masyarakat pascabencana, baik fisik maupun sosial, diperlukan untuk mengurangi dampak bencana. Terdapat sejumlah strategi yang dapat dilakukan, seperti memperbaiki dan memperkuat pembangunan gedung dan infrastruktur, mendorong pertumbuhan ekonomi daerah, serta memperkuat kesadaran dan kapasitas masyarakat terhadap bencana. Keberhasilan proses pemulihan tersebut ditentukan oleh kemampuan individu, rumah tangga, kelompok, dan lembaga dalam memanfaatkan dan mengakses sumber daya yang tersedia (Rivera-Muñoz, 2020).

Salah satu sumber daya pemulihan bencana adalah sumber daya ekonomi. Sumber daya ekonomi dapat diberikan untuk memulihkan dan menstabilkan situasi ekonomi masyarakat. Beberapa upaya yang dilakukan adalah 
memberikan kebijakan dukungan keuangan seperti pemberian kompensasi properti, penciptaan lapangan kerja, pelatihan keterampilan khusus, pemotongan pajak, pembelian aset, penawaran kredit dengan bunga rendah / tanpa bunga, dan pembelian asset (Sina, et.al, 2019).

Sumber daya pemulihan bencana dapat diperoleh dari dalam masyarakat (internal) atau dari eksternal (Sina, et.al, 2019). Sumber daya internal, baik individu maupun masyarakat, adalah sumber daya alam, aset keuangan, aset properti, dan modal sosial (seperti kepercayaan dan kepemimpinan) yang tersedia untuk lingkungan). Secara eksternal, kerabat, pemerintah, lembaga donor, dan Lembaga Swadaya Masyarakat dapat menyediakan sumber daya yang dibutuhkan, seperti dukungan keuangan, kompensasi aset properti dan ekonomi, pinjaman dengan suku bunga rendah, dan bantuan teknis dan non-teknis untuk pemulihan. Adapun akses ke kedua sumber daya tersebut dipengaruhi oleh sejumlah faktor, seperti jaringan sosial yang dimiliki, jenis kelamin, etnis, status, dan usia, yang dapat menyebabkan ketidaksetaraan peluang untuk memperoleh sumber daya.

Terdapat keterkaitan antara upaya manajemen bencana, termasuk pemulihan ekonomi, dengan pembangunan berkelanjutan. Respon yang tepat dapat mengurangi dampak bencana terhadap pembangunan. Secara ringkas, keterkaitan antara kebijakan pembangunan dan manajemen bencana tercantum dalam grafik 3 .

Terjadinya bencana pada dasarnya tergantung pada tingkat kerentanan individu, kelompok, lingkungan, dan institusi yang ada di dalam suatu masyarakat (Danuwikarsa, 2013). Salah satu faktor timbulnya bencana berasal dari bencana nonalam, yaitu bencana yang diakibatkan oleh peristiwa atau rangkaian peristiwa nonalam berupa epidemi dan wabah penyakit. Pandemi Covid-19 digolongkan sebagai bencana kesehatan oleh pemerintah Republik Indonesia melalui Keputusan Presiden Republik Indonesia Nomor 11 Tahun 2020 tentang Penetapan Kedaruratan Kesehatan Masyarakat Corona Virus Disease 2019 (Covid-19) pada tanggal 31 Maret 2020. Pemerintah menegaskan bahwa pandemi Covid-19 sebagai bencana nonalam sebagaimana tercantum dalam Keppres Nomor 12 Tahun 2020 tentang Penetapan Bencana Nonalam Penyebaran Corona Virus Diseases 2019 (Covid-19) sebagai bencana nasional.

Grafik 3. Siklus Manajemen Bencana dan Pembangunan Berkelanjutan

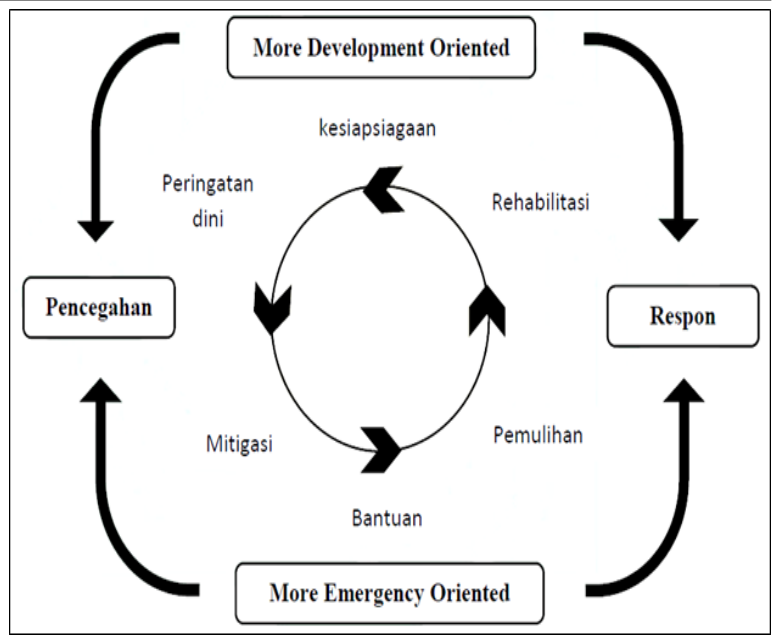

Sumber: Ubaidillah (2018)

\section{Produktivitas Tenaga Kerja Sektor Pertanian}

Sumber daya manusia merupakan modal pembangunan. Pemanfaatan atau pendayagunaan sumber daya manusia merupakan faktor utama dalam proses produksi. Sumber daya manusia yang dapat mendukung proses produksi dipengaruhi oleh faktor pendidikan, keahlian dan keterampilan. Tingkat pendidikan memiliki pengaruh positif terhadap pemikiran, perilaku, sikap, dan pola perilaku. Semakin tinggi pendidikan semakin baik penguasaan atas pikiran, sikap dan perilaku. Kondisi dan karakteristik tersebut dapat menimbulkan peningkatan kreativitas dan inovasi dari masyarakat yang sangat berguna dalam kegiatan produktif (Widyastuti, 2012).

Sumber daya manusia mempengaruhi aktivitas produksi. Keahlian dan keterampilan sumber daya manusia mempengaruhi kreativitas dan produktivitas, yang juga berkorelasi positif. Semakin tinggi tingkat ketrampilan dan keahlian, semakin besar pula kreativitas dan produktivitas sehingga lebih mampu menghasilkan produk berkualitas (Farah \& Sari, 2014).

Pertumbuhan penduduk yang menghasilkan keseimbangan angkatan kerja perlu dijaga agar proses kemajuan ekonomi dapat berkelanjutan. Di sisi lain, perubahan struktur demografi menjadi peluang untuk mengembangkan potensi ekonomi nasional (Jovovic, et. al., 2017). Kebijakan pengembangan sumber daya manusia menjadi kunci untuk memanfaatkan bonus penduduk.

Pertumbuhan penduduk membutuhkan upaya untuk memenuhi kebutuhan masyarakat dan peningkatan produksi. Peningkatan kompetensi penduduk melalui pemberian keterampilan dan kewirausahaan, kualitas pendidikan dan kesehatan. Strategi khusus perlu diterapkan melalui perluasan kewirausahaan sehingga dapat mendorong peningkatan produktivitas tenaga kerja pada penduduk usia produktif dan lanjut usia. Selain itu, 
diperlukan mobilisasi penduduk untuk mendukung pemerataan wilayah, penguasaan dan pemanfaatan teknologi, serta perluasan program jaminan sosial (Saliola, Mohamed Islam, \& Winker, 2020).

Pembangunan ekonomi yang berkualitas mendukung peningkatan produktivitas tenaga kerja (Cinnirella \& Streb, 2017). Di sisi lain, produktivitas tenaga kerja memainkan peran penting dalam membentuk daya saing sektor tertentu atau seluruh perekonomian, dan membantu menciptakan kondisi yang diperlukan untuk pembangunan ekonomi. Peningkatan produktivitas tenaga kerja merupakan bagian yang tidak terpisahkan dari pembangunan sumber daya manusia (Adam, 2016).

Produktivitas tenaga kerja adalah perbandingan antara hasil produksi terhadap jumlah pekerja. Indikator produktivitas pertanian yang sederhana dan umum adalah produktivitas tenaga kerja (yield/labour), yaitu hasil perkalian antara produktivitas lahan (yield/area) dan rasio tanah terhadap tenaga kerja (area/labour). Produktivitas tenaga kerja merupakan salah satu pendekatan terhadap kesejahteraan petani. Pertumbuhan produktivitas tenaga kerja berdampak pada kemiskinan petani. Pertumbuhan produktivitas tenaga kerja yang positif berdampak pada penurunan kemiskinan. Dalam kondisi tertentu, pekerja dapat menggantikan lahan karena peningkatan produktivitas tenaga kerja memungkinkan petani dapat mengolah lahan jauh lebih luas (Arifin, 2004).

Kemampuan bekerja (the ability to work) berdampak positif dan terpenting bagi produktivitas tenaga kerja (Damanhouri \& Rana, 2017). Kemampuan bekerja sangat dipengaruhi oleh faktor/derajat kesehatan (Knapp, 2007). Di samping itu, produktivitas tenaga kerja dipengaruhi faktor pendidikan dan teknologi (Chansarn, 2010).

Dunia telah dihadapkan pada perubahan teknologi yang sangat cepat. Pemanfaatan teknologi memungkinkan perluasan kesempatan kerja dan fleksibilitas dalam bekerja sehingga dapat meningkatkan produktivitas dan efisiensi proses produksi. Di samping itu, pemanfaatan teknologi digital semakin memberikan kemudahan dan kenyamanan kepada konsumen. Adaptasi teknologi telah mengubah cara dan pola kerja manusia. Penggunaan teknologi digital dapat mempercepat proses pemulihan bisnis dengan membangun rantai pasokan, komunikasi dan budaya, serta menggunakan teknologi digital untuk transaksi jualbeli (Munawar, et. al., 2020).

Perkembangan teknologi mempengaruhi keterkaitan antara petani, industri dan konsumen. Kebijakan jangka menengah dilaksanakan dengan membuat kebijakan yang meningkatkan volume produksi pertanian serta mendorong perubahan perilaku petani/konsumen. Dalam jangka panjang, kebijakan tersebut dapat memperkuat ketahanan pangan dan pertanian dengan tetap beradaptasi pada dinamika sosial ekonomi sehingga mendukung pertumbuhan ekonomi yang berkelanjutan (Rusdiana \& Talib, 2020).

Program pelatihan dapat meningkatkan produktivitas penduduk. Program pelatihan berfungsi membekali masyarakat dengan keterampilan dan keahlian yang relevan dengan bidang kerja atau berwirausaha. Salah satu upaya program pelatihan pada masa pandemi Covid-19 dilakukan melalui program kartu prakerja. Manfaat yang diperoleh dari program Kartu Prakerja, yaitu: 1) meringankan beban biaya pelatihan karyawan; 2) meringankan biaya dalam memperoleh informasi pelatihan; 3) menjembatani individu dengan kesesuaian bidang pekerjaan; 4) melengkapi kompetensi yang telah diperoleh dari pendidikan formal; dan 5) meringankan beban masyarakat dari dampak pandemi Covid-19.

Peningkatan produktivitas pertanian adalah salah satu cara untuk mengurangi kemiskinan di sektor pertanian. Kenaikan harga produk pertanian dapat meningkatkan nilai tukar dan kesejahteraan petani, tetapi petani miskin akan memikul beban kenaikan harga pangan lebih besar. Peningkatan harga produk pertanian akan menguntungkan pada produk pertanian yang memiliki nilai ekspor karena kenaikan tersebut dapat meningkatkan pendapatan para petani. Peningkatan produksi tani dalam hasil pertanian dapat dilakukan melalui perbaikan kualitas produk yang dihasilkan oleh SDM pertanian. Peningkatan kualitas SDM sektor pertanian dilakukan melalui penyuluhan atau pelatihan. Bekal pengetahuan dan keterampilan dapat membantu petani meningkatkan produksi secara maksimal sehingga petani dapat meningkatkan hasil produksi yang akan berdampak kesejahteraan petani. Pengetahuan dan keterampilan yang diperoleh melalui kegiatan pendidikan dan pelatihan mendukung penurunan kemiskinan, begitu pula dengan melakukan kegiatan untuk meningkatkan pemberdayaan (Baah-Mintah et.al, 2018).

Produktivitas tenaga kerja sektor pertanian dipengaruhi oleh kapasitas produksi dan kualitas sumber daya manusia pelaku sektor pertanian (Arifin, 2004). Kualitas SDM ditentukan oleh tingkat pembangunan manusia di sektor pertanian yang mencakup faktor pendidikan, kesehatan, dan pendapatan/kesejahteraan. Pemberian bantuan teknis kepada petani, terutama melalui pendidikan dan pelatihan mendukung peningkatan kualitas sumber daya manusia dan produktivitas pertanian.

Grafik 4. Peningkatan Produktivitas Tenaga Kerja Sektor Pertanian 


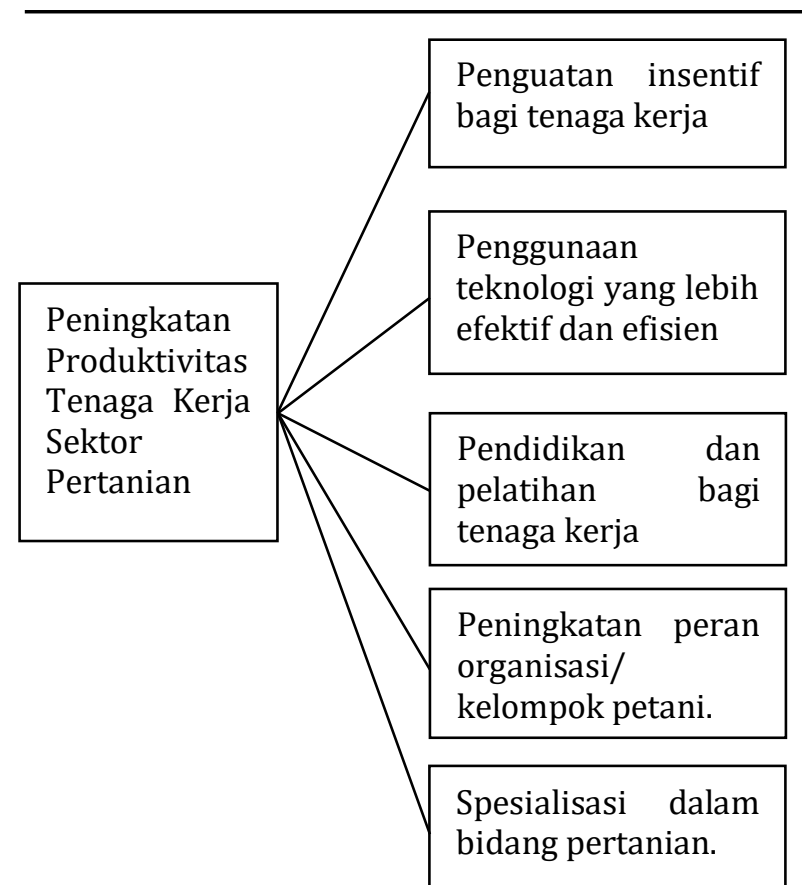

Sumber: hasil olahan peneliti (2021)

Grafik 4 menunjukkan upaya peningkatan produktivitas tenaga kerja sektor pertanian perlu didukung oleh sejumlah rangkaian kegiatan yang terprogram terkait pengembangan kapasitas sumber daya manusia sektor pertanian. Program tersebut mencakup penguatan insentif bagi tenaga kerja sektor pertanian, penggunaan teknologi yang lebih efektif dan efisien oleh tenaga kerja sektor pertanian, pendidikan dan pelatihan bagi tenaga kerja sektor pertanian, peningkatan peran organisasi/kelompok petani, serta adanya spesialisasi dalam bidang pertanian.

Ada dua efek untuk produktivitas pertanian yang lebih tinggi. Pertama, terdapat efek keunggulan komparatif yang statis, yaitu sektor pertanian akan menarik tenaga kerja sektor lain karena tingkat produktivitasnya yang lebih tinggi. Kedua, terdapat pengaruh peningkatan pendapatan, yaitu produktivitas pertanian yang lebih tinggi meningkatkan hasil pertanian, yang meningkatkan penerimaan pajak dan pengeluaran publik untuk infrastruktur. Infrastruktur yang memadai akan mendorong pertumbuhan ekonomi.

Kegiatan dan rantai pasokan pertanian, umumnya, dikecualikan dari pedoman pembatasan sosial. Namun, implementasi pedoman tersebut dapat berdampak pada mobilitas yang menyebabkan kekurangan tenaga kerja dan penurunan produksi pertanian. Hal itu menuntut antisipasi terhadap terjadinya risiko adanya pembatasan sosial terhadap sektor pertanian.

\section{METODOLOGI PENELITIAN}

Penelitian ini menggunakan pendekatan kualitatif. Proses analisis dilakukan secara deskriptif untuk memberikan gambaran mengenai obyek yang diteliti menggunakan konsep penanganan bencana, teori keuangan publik, dan ekonomi pertanian. Data yang diperoleh berasal dari studi kepustakaan dikumpulkan, dianalisis dan disusun mengikuti alur sistematika pembahasan.

\section{HASIL DAN PEMBAHASAN}

\section{Pandemi Covid-19 dan Produktivitas Tenaga Kerja Sektor Pertanian.}

Wabah Covid-19 menyerang semua sektor. Adanya pembatasan sosial sebagai upaya mengurangi risiko pandemi mengakibatkan kegiatan ekonomi berkurang. Pandemi Covid-19 mengganggu beberapa aktivitas di bidang pertanian dan rantai pasokan. Penutupan hotel, restoran, toko makanan, dan kedai minuman selama pembatasan sosial telah menekan penjualan produk pertanian. Pembatasan layanan makanan telah mempengaruhi aktivitas rantai pasokan, termasuk di sektor pertanian.

Pada tahun 2020, Sektor Pertanian menjadi salah satu sektor yang mencapai pertumbuhan ekonomi tertinggi. Namun, laju pertumbuhan PDB Sektor Pertanian tersebut masih lebih rendah daripada periode sebelum terjadi pandemi Covid-19 (Grafik 5).

Grafik 5. Laju Pertumbuhan PDB Sektor Pertanian Tahun 2016 - 2020

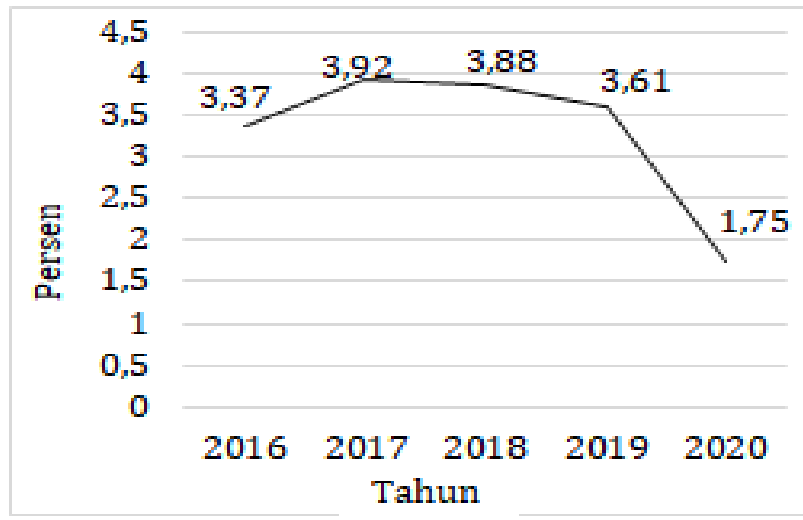

Sumber: BPS (2021a)

Karakteristik virus yang mudah menyebar dari manusia ke manusia sangat mempengaruhi perekonomian. Sektor pertanian di Indonesia mengalami kelangkaan stok dan harga komoditas yang terus meningkat, sedangkan di sisi lain permintaan konsumen masih tinggi seperti pada komoditas bawang putih, daging sapi, dan gula pasir (Tabel 3). Sistem pemasaran juga terhambat karena imbauan pemerintah untuk tidak bepergian jauh dan sistem transportasi yang terbatas.

Tabel 3. Perkiraan Ketersediaan dan Kebutuhan Pangan Pokok Nasional Periode Mei Sampai Dengan Desember 2020

(Dalam Ribuan Ton) 


\begin{tabular}{|c|c|c|c|c|c|c|c|}
\hline \multirow[b]{2}{*}{ No } & \multirow[b]{2}{*}{ Komoditas } & \multicolumn{4}{|c|}{ Perkiraan Ketersediaan } & \multirow[b]{2}{*}{$\begin{array}{l}\text { Kebutu- } \\
\text { han }\end{array}$} & \multirow[b]{2}{*}{$\begin{array}{c}\text { Neraca } \\
\text { s.d. } \\
\text { Des'20 }\end{array}$} \\
\hline & & $\begin{array}{c}\text { Stok } \\
\text { Akhir } \\
\text { April'20 }\end{array}$ & $\begin{array}{c}\text { Produksi } \\
\text { / Redistri } \\
\text {-busi/ } \\
\text { Realokasi }\end{array}$ & $\begin{array}{c}\text { Rencana } \\
\text { Impor }\end{array}$ & Jumlah & & \\
\hline 1 & 2 & 3 & 4 & 5 & $6=3+4+5$ & 7 & $8=6-7$ \\
\hline 1 & Beras & 7.409 & 18.794 & - & 26.203 & 20.090 & 6.113 \\
\hline 2 & Jagung & 950 & 11.258 & - & 12.208 & 10.790 & 1.418 \\
\hline 3 & $\begin{array}{l}\text { Bawang } \\
\text { Merah }\end{array}$ & 78 & 624 & - & 702 & 672 & 30 \\
\hline 4 & $\begin{array}{l}\text { Bawang } \\
\text { Putih } \\
\end{array}$ & 21 & 17 & 603 & 642 & 377 & 265 \\
\hline 5 & Cabai Besar & & 762 & - & 762 & 730 & 31 \\
\hline 6 & Cabai Rawit & & 755 & - & 755 & 675 & 80 \\
\hline 7 & $\begin{array}{l}\text { Daging } \\
\text { Sapi/ } \\
\text { Kerbau }\end{array}$ & 165 & 301 & 282 & 749 & 354 & 395 \\
\hline 8 & $\begin{array}{l}\text { Daging } \\
\text { Ayam Ras }\end{array}$ & - & 2.447 & - & 2.447 & 1.552 & 894 \\
\hline 9 & $\begin{array}{l}\text { Telur Ayam } \\
\text { Ras }\end{array}$ & - & 8.411 & - & 8.411 & 8.160 & 250 \\
\hline 10 & Gula Pasir & 213 & 2.314 & 612 & 3.140 & 1.855 & 1.285 \\
\hline$\overline{11}$ & $\begin{array}{r}\text { Minyak } \\
\text { Goreng }\end{array}$ & 5.237 & 5.529 & - & 10.766 & 3.480 & 7.285 \\
\hline
\end{tabular}

Sumber: Kementerian Pertanian (2020b)

Berdasarkan studi literatur, bencana mengakibatkan kerugian ekonomi bagi rumah tangga kaya dan miskin (De Silva \& Kawasaki, 2018). Terdapat dampak yang dapat mempengaruhi sektor pertanian terkait dengan tingkat risiko tertular virus dan nilai ekonomi akibat pandemi. Di samping itu, Rivera-Muñoz (2020) dan Sina et al (2019) menyebutkan bahwa peran pemerintah melalui alokasi anggaran diperlukan untuk memulihkan dampak kondisi masyarakat yang terkena bencana. Secara langsung, dampak kerugian ekonomi dari pandemi di sektor pertanian terkait dengan realokasi sumber daya (pergeseran anggaran) sektor pertanian untuk digunakan dalam rangka penanganan, pengendalian, dan pencegahan pandemi. Selain itu, terdapat realokasi/pergeseran anggaran belanja (APBN) pada kementerian/lembaga untuk pengembangan/penyediaan vaksin atau perawatan medis (pengobatan) pasien yang terinfeksi.

Realokasi anggaran untuk dana penanganan Covid-19 berasal dari belanja pemerintah pusat, transfer ke daerah dan dana desa, serta pembiayaan dalam APBN. Pemerintah melakukan pemotongan anggaran untuk konsolidasi fiskal, dan belanja kegiatan yang tidak dapat dilaksanakan dalam kondisi pandemi. Adapun kegiatan yang difokuskan kembali sehingga dananya dialokasikan kembali untuk program penanggulangan Covid-19, mencakup perjalanan dinas dan kegiatan lainnya yang tidak dapat dilakukan pada periode darurat (Puspasari, 2020).

Respon terhadap pandemi Covid-19 mencakup aspek keuangan pemerintah. Anggaran Kementerian Pertanian termasuk dalam kebijakan refocusing kegiatan dan realokasi anggaran tahun
2020. Adapun nilai anggaran yang direalokasi untuk penanganan pandemi Covid-19 sebesar Rp1,85 triliun. Refocusing kegiatan dan realokasi anggaran tersebut digunakan untuk: (1) mendukung pencegahan penularan Covid-19 yang mencakup penyediaan sarana dan peralatan medis, suplemen dan daya tahan tubuh, serta sterilisasi ruangan sebesar Rp45 miliar; (2) mendukung pengamanan ketersediaan pangan melalui kegiatan operasi pasar pangan murah dan stabilisasi harga pangan, bantuan penyerapan gabah dan transportasi/angkutan distribusi pangan, pemantapan ketersediaan dan stabilisasi pasokan sebesar Rp198,95 miliar; (3) mendukung kegiatan jaring pengaman sosial (program padat karya) sebesar Rp1,60 triliun (Kementerian Pertanian, 2020).

Arouri, Nguyen, \& Youssef (2015) menyebutkan berbagai dampak bencana terhadap sektor usaha dan ekonomi. Berkaitan dengan pandemi Covid-19 terhadap sektor pertanian, upaya pencegahan penyebaran virus mengakibatkan sejumlah sektor ekonomi (non pertanian) akan mengalami kendala terkait ketersediaan tenaga kerja. Ketersediaan tenaga kerja cenderung berkurang karena infeksi virus atau karena kebijakan bekerja dari rumah. Dalam jangka panjang, penurunan pendapatan individu dan perusahaan dapat menimbulkan ancaman kemiskinan, penurunan status kesehatan dan pendidikan. Selanjutnya, situasi pandemi dapat menyebabkan penurunan produktivitas tenaga kerja. Di sisi lain, Pandemi Covid-19 memicu migrasi penduduk yang bekerja antar sektor ekonomi. Pada tahun 2020, sektor Pertanian, Kehutanan, dan Perikanan mengalami peningkatan persentase lapangan pekerjaan terbesar (2,23 persen), diikuti sektor Perdagangan Besar dan Eceran $(0,46$ persen); dan sektor Jasa Lainnya (0,05 persen). Adapun sektor ekonomi yang mengalami penurunan lapangan pekerjaan terbesar, berturutturut, sektor Industri Pengolahan (1,30 persen); sektor Konstruksi $(0,46$ persen), dan sektor Jasa Pendidikan (0,29 persen). Pada Agustus 2020, jumlah penduduk yang bekerja sebanyak 128,5 juta jiwa atau turun dibandingkan Agustus 2019 sebanyak 128,8 juta jiwa. Selama periode Agustus 2019 sampai dengan Agustus 2020, jumlah penduduk yang bekerja pada Sektor Pertanian bertambah sebanyak 2,78 juta orang. Hal itu menunjukkan terdapat perpindahan penduduk bekerja dari sektor lain menuju sektor pertanian (Grafik 6).

Pandemi Covid-19 berdampak terhadap upah buruh. Rata-rata upah buruh dalam periode Agustus 
Grafik 6. Persentase Penduduk Bekerja Menurut Lapangan Pekerjaan Utama 2018 - 2020

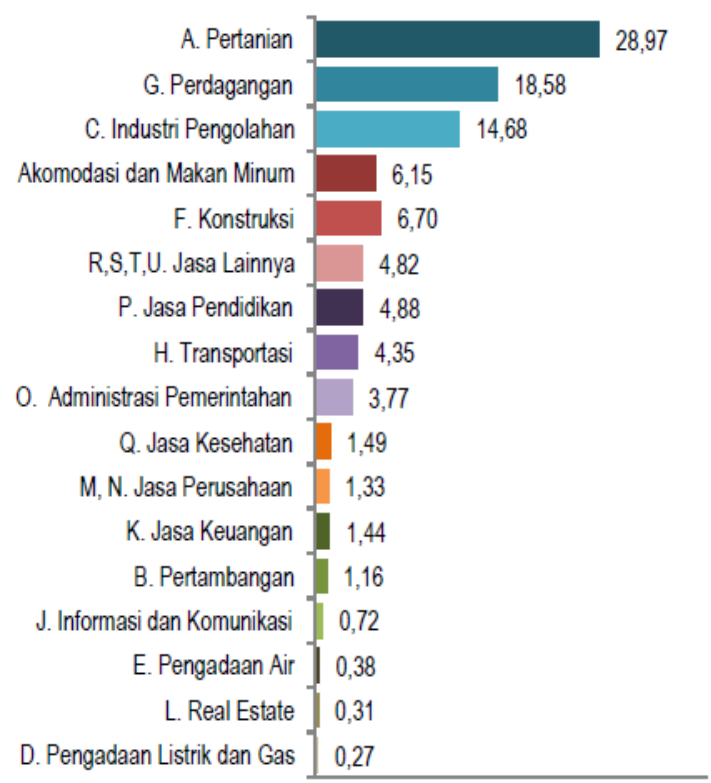

Agustus 2018

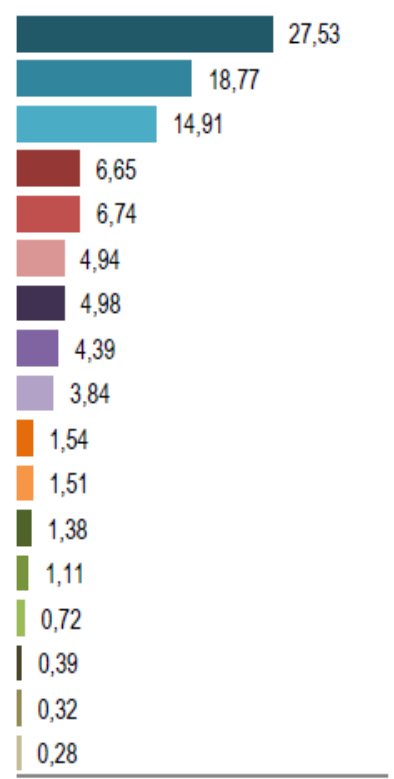

Agustus 2019

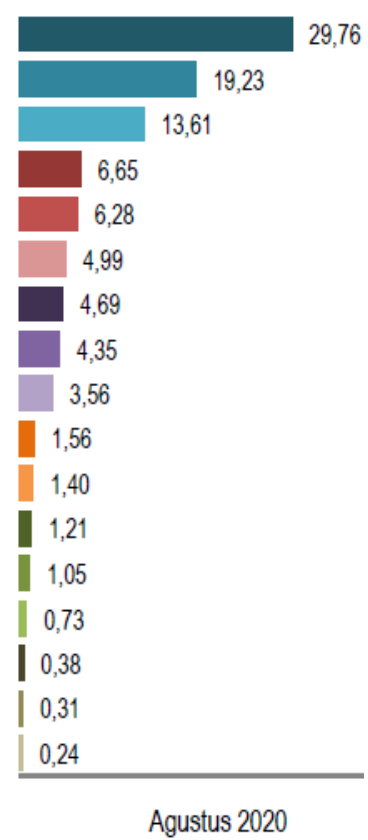

Sumber: BPS (2020d)

2019 sampai dengan Agustus 2020 mengalami penurunan sebesar minus 5,20 persen. Adapun penurunan rata-rata upah buruh sektor Pertanian mencapai minus 5,94 persen atau lebih dalam daripada penurunan rata-rata upah buruh secara nasional (Grafik 7). Penurunan upah buruh sektor pertanian dapat memicu peningkatan penduduk miskin di sektor pertanian. Selain itu, mengingat sebagian besar pekerja sektor pertanian bertempat tinggal di perdesaan, penurunan upah buruh sektor pertanian dapat meningkatkan jumlah penduduk miskin di perdesaan (Abidin, 2015).

Perpindahan tenaga kerja dari sektor non pertanian ke sektor pertanian belum diiringi dengan peningkatan nilai output pertanian sehingga rata-rata upah buruh di Sektor Pertanian mengalami penurunan. Perpindahan jumlah tenaga kerja ke sektor pertanian yang relatif cepat belum disertai dengan keterampilan dan keahlian pertanian sehingga produktivitas tenaga kerja sektor pertanian rendah. Selain faktor kapasitas tenaga kerja sektor pertanian yang terbatas, pemanfaatan teknologi di sektor pertanian masih belum efektif dan efisien. Perpindahan tenaga kerja ke sektor pertanian menurunkan balas jasa tenaga kerja sektor pertanian sebagaimana tercermin pada rata-rata upah buruh sektor pertanian lebih rendah daripada rata-rata upah buruh secara nasional. Pada Agustus 2020, upah buruh yang bekerja di Sektor Pertanian sebesar Rp1,91 juta per bulan dan rata-rata upah buruh secara nasional sebesar Rp2,76 juta. Upah buruh sektor pertanian tersebut mengalami penurunan dibandingkan sebelum

terjadinya pandemi Covid-19 yang tercatat sebesar Rp2,03 juta per bulan. Di samping itu, buruh pada kategori Pertanian menerima upah terendah setelah buruh pada kategori Jasa Lainnya sebesar Rp1,69 juta per bulan (BPS, 2020d).

Secara global, dampak Covid-19 pada pertanian bertransmisi melalui rantai pasokan. Sejak awal Mei 2020, harga internasional komoditas beras telah naik. Hal ini terkait dengan pembatasan ekspor Vietnam, yang merupakan pemasok utama (Erokhin \& Gao, 2020). Data BPS menyebutkan bahwa selama tahun 2020 terjadi inflasi sebesar 1,68 persen. Kenaikan inflasi tersebut sebagian besar disebabkan kenaikan harga pada kelompok makanan, minuman, dan tembakau yang memiliki keterkaitan dengan produk pertanian dengan andil/sumbangan inflasi sebesar 0,91 persen. Andil inflasi kelompok makanan, minuman, dan tembakau pada masa pandemi Covid-19 tersebut mengalami kenaikan dibandingkan tahun 2019 sebesar 0,83 persen (BPS, 2021b).

Gangguan dalam logistik dan layanan transportasi serta adanya pembatasan sosial berdampak pada penyediaan sarana produksi bagi petani, seperti pestisida, pupuk dan benih. Kekurangan atau mahalnya harga perlengkapan perlindungan diri, seperti hand sanitizer dan masker wajah, menyebabkan penundaan dan masalah tambahan. Hal itu dialami Tiongkok yang mengalami penurunan produksi pestisida setelah pabrik ditutup (Bochtis et.al., 2020). Pembatasan sosial di Italia telah mengakibatkan penurunan produktivitas tenaga kerja, kenaikan biaya tenaga 
Grafik 7. Persentase Perubahan Rata-rata Upah Buruh Menurut Lapangan Pekerjaan Tahun 2019 - 2020

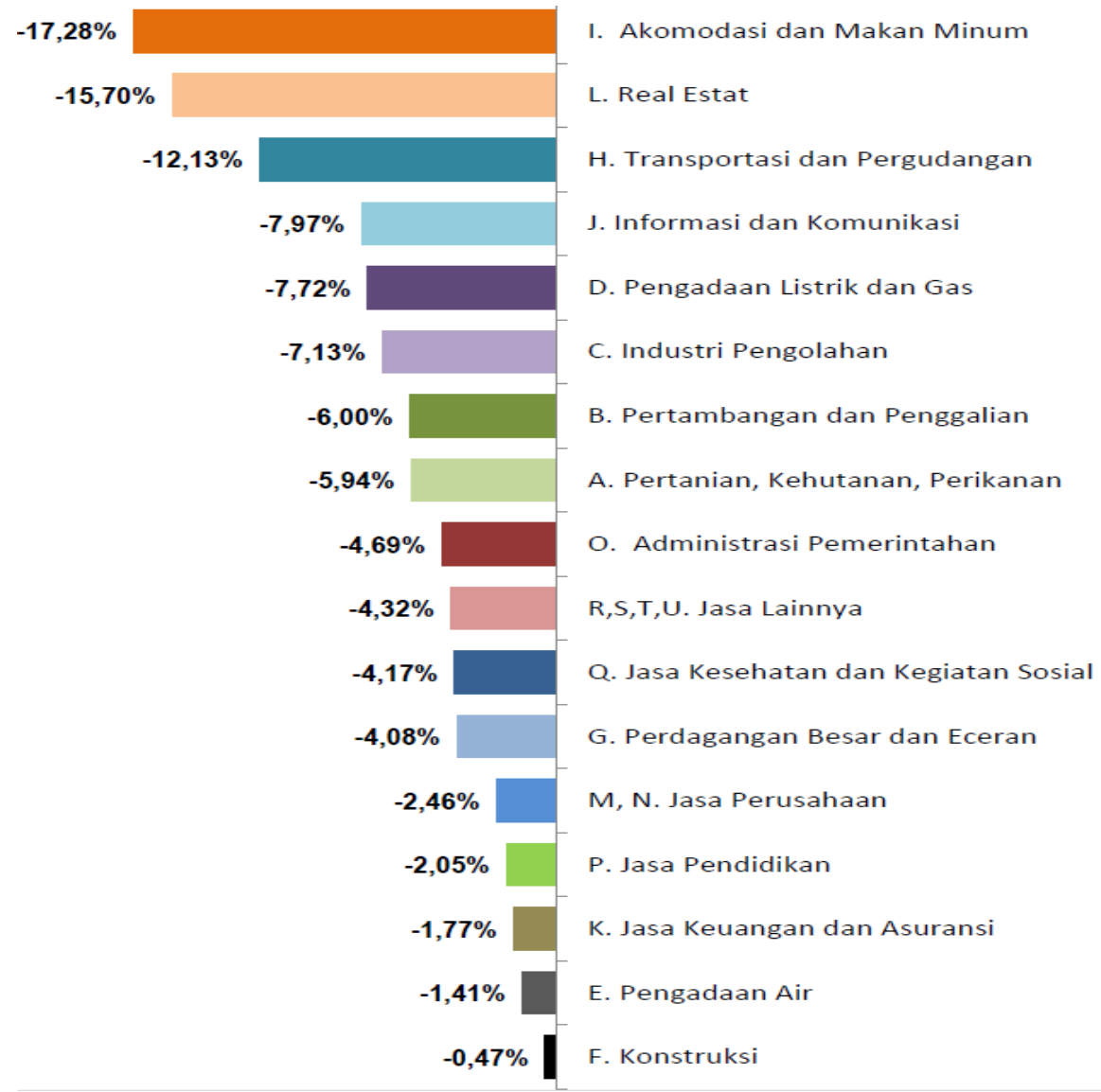

Sumber: BPS (2020d)

kerja dan transportasi, kerugian pendapatan bagi petani (Cortignani, Carulli, \& Dono, 2020). Di sisi lain, gangguan besar pada rantai pasokan sebagai akibat dari pembatasan sosial telah memicu penurunan permintaan global di sektor jasa makanan (Swinnen \& McDermott, 2020). Pembatasan transportasi juga menghambat kemampuan petani dan nelayan untuk mengakses pasar sehingga membatasi kapasitas produktif (Bochtis et.al., 2020). Di Indonesia, pandemi Covid19 telah mengakibatkan sejumlah daerah mengalami kesulitan dalam memperoleh sarana produksi dan pemasaran hasil pertanian. Di sisi lain, beban pengeluaran petani bertambah karena kenaikan harga sarana produksi. Kondisi tesebut menyebabkan sebagian petani di sejumlah daerah terpaksa memanen tanaman lebih awal untuk menghindari beban pengeluaran yang lebih besar (Febrianto, 2021). Data pada tabel 4 menunjukkan adanya tren penurunan Nilai Tukar Petani dan Nilai Tukar Usaha Pertanian subsektor Tanaman Pangan pada bulan Oktober - Desember 2020.

Faktor kesehatan petani dapat terpengaruh karena banyaknya petani yang berusia lanjut. Hal itu meningkatkan risiko/kerentanan pekerja sektor pertanian sehingga dapat mengganggu produksi pertanian. Di samping itu, risiko penyebaran Covid19 yang cepat dan tidak tekendali dapat mempengaruhi tenaga kerja pertanian sehingga mengurangi kegiatan/bekerja. Tenaga kerja sektor pertanian yang jatuh sakit atau merawat anggota keluarga atau anak yang sakit, karena penutupan sekolah, yang selanjutnya berdampak pada ketersediaan tenaga kerja. Konsekuensi ini berdampak pada produksi pertanian.

Tabel 4. Nilai Tukar Petani dan Nilai Tukar Usaha Pertanian Subsektor Tanaman Pangan Oktober - Desember 2020

\begin{tabular}{lcc}
\hline Bulan & $\begin{array}{c}\text { Nilai Tukar } \\
\text { Petani } \\
\text { (persen) }\end{array}$ & $\begin{array}{c}\text { Nilai Tukar } \\
\text { Usaha Pertanian } \\
\text { (persen) }\end{array}$ \\
\hline Oktober & $-0,10$ & $-0,01$ \\
\hline November & $-0,54$ & $-0,27$ \\
\hline Desember & $-0,54$ & $-0,19$ \\
\hline
\end{tabular}

Sumber: BPS (2021) 
Berdasarkan kategori usia, tenaga kerja yang bekerja di sektor pertanian dapat dibagi ke dalam 3 kelompok. Adapun jumlah tenaga kerja sektor pertanian sebanyak 34,99 juta jiwa, terdiri dari kelompok usia muda (15-24 tahun) sebanyak 3,30 juta jiwa, usia prima (25-59 tahun) sebanyak 24,31 juta jiwa, dan usia tua (di atas 60 tahun) sebanyak 7,38 juta jiwa. Jumlah tenaga kerja sektor pertanian dalam kelompok usia tua yang lebih banyak daripada kelompok usia muda menunjukkan bahwa sektor pertanian kurang diminati oleh generasi muda (Kementerian Pertanian, 2020a). Selain terhambatnya proses regenerasi, data tersebut menimbulkan kerentanan daya tahan kesehatan tenaga kerja sektor pertanian terhadap risiko penyebaran Covid-19.

Tabel 5 menunjukkan gambaran sektor pertanian dan estimasi dampak pandemi Covid-19 terhadap Sektor Pertanian Indonesia dan ASEAN. Pada tahun 2014 - 2019, jumlah tenaga kerja sektor pertanian di ASEAN sebanyak 107,66 juta jiwa. Adapun jumlah tenaga kerja pertanian terbanyak berada di Indonesia sebesar 40,22 juta orang atau 37,4 persen dari seluruh negara-negara ASEAN. Jumlah tenaga kerja pertanian di ASEAN menunjukkan kecenderungan penurunan dalam periode tahun 2014-2019. Adapun pertumbuhan jumlah tenaga kerja sektor pertanian di Indonesia selama tahun 2014 - 2019 sebesar minus 1,77 persen per tahun.

Proporsi tenaga kerja sektor pertanian terhadap total tenaga kerja di Indonesia sebesar 29 persen, lebih rendah daripada rata-rata negara ASEAN sebesar 31 persen. Negara-negara ASEAN lainnya memiliki proporsi tenaga kerja sektor pertanian terhadap total tenaga kerja lebih besar, seperti adalah Laos, Myanmar, Timor Leste, Kamboja, dan Thailand masing-masing sebesar 62 persen, 49 persen, 44 persen, 32 persen, dan 32 persen. Pandemi Covid-19 akan meningkatkan proporsi tenaga kerja sektor pertanian sebagai akibat perpindahan tenaga kerja non pertanian ke dalam sektor pertanian.

Adanya shifting tenaga kerja yang disebabkan oleh pandemi Covid-19 dapat menunda penanaman. Di samping mengganggu sisi produksi, pandemi Covid-19 dapat menghambat pemasaran produk pertanian, menurunkan pendapatan pekerja dan produktivitas sektor pertanian. Pada tahun 2018, produktivitas tenaga kerja sektor pertanian berdasarkan jumlah produksi hasil pertanian tanaman/crops dan daging hewan ternak/livestock) di ASEAN mencapai 5,272 ton per orang.

Di ASEAN, pandemi Covid-19 diperkirakan mengakibatkan penurunan jumlah tenaga kerja sektor pertanian yang akan berdampak kepada penurunan produksi pertanian sebesar 3,11 persen. Di antara negara-negara ASEAN yang paling
Tabel 5. Gambaran Sektor Pertanian dan Estimasi Dampak Pandemi Covid-19 Terhadap Sektor Pertanian Indonesia dan ASEAN

\begin{tabular}{|c|c|c|}
\hline Uraian & Indonesia & ASEAN \\
\hline $\begin{array}{lr}\text { Rata-rata } & \text { Jumlah } \\
\text { Angkatan Kerja Tahun } \\
2014-2019 \text { (juta orang) }\end{array}$ & 128,48 & 323,46 \\
\hline $\begin{array}{l}\text { Rata-rata Jumlah Tenaga } \\
\text { Kerja Sektor Pertanian } \\
\text { Tahun 2014-2019 (juta } \\
\text { orang) }\end{array}$ & 40,22 & 107,66 \\
\hline \begin{tabular}{lrr} 
Share & Tenaga & Kerja \\
Sektor & \multicolumn{2}{c}{ Pertanian } \\
Terhadap & Total & Tenaga \\
Kerja & Tahun & 2019 \\
(persen) & & \\
\end{tabular} & 29 & 31 \\
\hline \begin{tabular}{lrr} 
Laju & \multicolumn{2}{c}{ Pertambahan } \\
Tenaga & Kerja & Sektor \\
Pertanian, 2014 & -2019 \\
(persen per tahun)
\end{tabular} & $-1,77$ & $-2,31$ \\
\hline $\begin{array}{lr}\text { Kontribusi } & \text { Sektor } \\
\text { Pertanian Terhadap PDB } \\
2014-2019 \quad \text { (miliar } \\
\text { USD) }\end{array}$ & 128,69 & 278,02 \\
\hline $\begin{array}{lr}\text { Rata-rata } & \text { Tingkat } \\
\text { Pertumbuhan } & \text { PDB } \\
\text { Sektor Pertanian Per } \\
\text { Tahun (2014 - 2019, } \\
\text { milar USD) }\end{array}$ & 4,09 & $-0,76$ \\
\hline $\begin{array}{lr}\text { Estimasi } & \text { Perubahan } \\
\text { Volume } & \text { Produksi } \\
\text { Pertanian } & \text { Akibat } \\
\text { Pandemi } & \text { Covid-19 } \\
\text { (persen) } & \\
\end{array}$ & $-3,28$ & $-3,11$ \\
\hline $\begin{array}{l}\text { Estimasi Dampak Covid- } \\
19 \text { Terhadap PDB Sektor } \\
\text { Pertanian (miliar USD) }\end{array}$ & $-2,022$ & $-3,758$ \\
\hline $\begin{array}{l}\text { Perubahan dalam PDB } \\
\text { (persen) }\end{array}$ & $-1,40$ & $-1,40$ \\
\hline $\begin{array}{lr}\text { Estimasi } & \text { Dampak } \\
\text { Pandemi } & \text { Covid-19 } \\
\text { Terhadap Peningkatan } \\
\text { Rasio Kemiskinan Sektor } \\
\text { Pertanian (persen) }\end{array}$ & 2,07 & 2,24 \\
\hline
\end{tabular}

terpengaruh oleh penurunan tenaga kerja sektor pertanian adalah Vietnam, Kamboja, dan Indonesia. Secara agregat, penurunan produksi pertanian Indonesia diperkirakan sebesar 3,28 persen. Selanjutnya, penurunan produksi pertanian tersebut berkontribusi terhadap penurunan sektor pertanian dalam PDB di ASEAN sebesar 1,4 persen (Gregorioa dan Ancog, 2020).

Pemerintah telah menetapkan target produksi empat komoditas pertanian utama pada 2021. Target tersebut mencakup produksi padi sebesar 63,5 juta ton, jagung 26 juta ton, kedelai $480 \mathrm{ribu}$ ton, dan daging sapi/kerbau 463 ribu ton. Namun, pandemi Covid-19 dapat mengganggu pencapaian target tersebut. Terdapat skenario dampak 
pandemi Covid-19 yang berkaitan dengan produksi pangan (Rohmani, 2020). Situasi pandemi Covid-19 yang meluas dapat menimbulkan kekhawatiran dan mempengaruhi produktivitas tenaga kerja sektor pertanian pangan sehingga tingkat produksi pertanian diperkirakan mengalami penurunan sebesar 10 persen.

Berdasarkan studi literatur, upaya peningkatan produktivitas tenaga kerja sektor pertanian memerlukan dukungan pemerintah. Berkaitan dengan pandemi Covid-19, pemerintah turut memberikan fokus terhadap sektor pertanian (Arifin, 2004; Knapp, 2007; Chansarn, 2010; Damanhouri \& Rana, 2017; Saliola, Mohamed Islam, \& Winker, 2020). Terdapat 2,44 juta petani dalam kategori miskin yang memerlukan perhatian khusus. Jumlah tersebut terdiri dari petani penggarap dan buruh tani yang sebagian besar menjadi pekerja di lahan milik orang lain. Di sisi lain, Pemerintah berperan penting dalam menjaga dan meningkatkan kesejahteraan tenaga kerja pertanian yang merupakan produsen bahan pangan. Upaya tersebut dilakukan melalui program perlindungan sosial dan paket bantuan pemerintah bagi tenaga kerja sektor pertanian agar tetap produktif.

Program kartu prakerja dapat dipandang sebagai upaya perluasan akses tenaga kerja sektor pertanian ke pasar sehingga dapat meningkatkan penggunaan/pemasaran produk pertanian. Inovasi teknologi dan manajemen dapat membantu mengatasi berbagai kendala terkait efek negatif dari pandemi. Inovasi tersebut dapat mempertahankan kontinuitas kegiatan di sektor pertanian dan rantai pasokan yang terkait sektor pertanian agar tetap bekerja. Hal itu dapat didorong melalui pemasaran produk pertanian ke rumah tangga dan melalui $e$ commerce.

Peningkatan akses pasar produk-produk pertanian dapat menjaga agar rantai pasokan berfungsi dengan baik. Dukungan/intervensi kebijakan yang terpadu dan strategis yang melibatkan peran sektor swasta dan dukungan/intervensi pemerintah (BalwinderSingh, et al., 2020). Kemitraan antara pemerintah, termasuk pemerintah daerah, dan swasta dapat mendorong/menjaga produktivitas pertanian.

\section{Program PEN dan Produktivitas Tenaga Kerja Sektor Pertanian}

Covid-19 merupakan pandemi dengan tingkat penyebaran tinggi dan mempengaruhi sektor ketenagakerjaan. Covid-19 berdampak pada pekerja bebas sektor pertanian atau pekerja "serabutan" yang bekerja jika ada permintaan bekerja. Terdapat pekerja bebas yang tidak memperoleh pesanan/order sebanyak 55 persen, dan 38 persen pesanan/order berkurang.
Berdasarkan aspek pendapatan, pekerja bebas tidak memiliki pendapatan selama masa pandemi Covid19 sebanyak 58 persen dan pekerja yang mengalami penurunan pendapatan sampai 30 persen sebanyak 28 persen (Ngadi, 2020).

Dampak Covid-19 terhadap aspek ekonomi cukup masif. Pertumbuhan ekonomi global semakin memburuk selama penyebaran wabah Covid-19. Tindakan pembatasan sosial dan pembatasan mobilitas dalam skala lokal maupun internasional menyebabkan pertumbuhan ekonomi yang stagnan di semua sektor. Sebagian besar pabrik yang ditutup selama Covid-19. Kondisi ini berdampak pada rendahnya produktivitas karena rendahnya permintaan dan rendahnya penggunaan transportasi. Hal ini mengakibatkan tingginya angka pengangguran.

Berdasarkan studi literatur, Knapp (2007), dan Damanhouri \& Rana (2017) menyebutkan bahwa faktor kesehatan mempengaruhi kemampuan bekerja dan produktivitas tenaga kerja. Pandemi Covid-19 mengancam kesehatan masyarakat dan memicu penurunan produktivitas tenaga kerja di Indonesia. Hal tersebut sangat mempengaruhi lambatnya pertumbuhan ekonomi tahun 2020. Penurunan besar terjadi hampir di semua sektor.

Peningkatan kompetensi akan meningkatkan produktivitas tenaga kerja pertanian (Arifin, 2004). Peningkatan kualitas sumber daya manusia sektor pertanian dapat dilakukan melalui pemberian keterampilan dan kewirausahaan, kualitas pendidikan dan kesehatan (Baah-Mintah et.al, 2018)

Penyebaran Covid-19 mempengaruhi semua jenis perdagangan, produk pertanian, dan produk non pertanian. Mitigasi risiko akibat penurunan output pertanian dapat diatasi melalui peningkatan peran dan produktivitas petani. Alokasi sumber daya ke bidang pertanian untuk memastikan pelaksanaan kegiatan ekonomi di bidang pertanian dengan tepat selama wabah Covid-19 dapat menekan kemiskinan dan meningkatkan kesejahteraan petani. Beberapa kebijakan dan strategi yang dilakukan adalah: (1) pemberdayaan petani melalui program padat karya berbasis agribisnis (2) membuka pelatihan kerja bagi petani, masyarakat dengan status tingkat ekonomi rendah dan pengangguran dengan insentif tunjangan (3) meningkatkan kesejahteraan petani di pedesaan, dan (4) memastikan ketersediaan dan akses pangan pokok bagi seluruh masyarakat dengan harga yang wajar (Kementerian Pertanian, 2020).

Strategi penanganan pandemi Covid-19 membawa konsekuensi perubahan anggaran (APBN) tahun 2020. Pandemi Covid-19 berdampak pada penurunan anggaran pendapatan negara dan 
peningkatan anggaran belanja negara. Terdapat perubahan anggaran pendapatan negara dari semula sebesar Rp2.233 triliun menjadi Rp1.699 triliun. Sementara itu, anggaran belanja negara mengalami kenaikan dari semula sebesar Rp2.540 triliun menjadi sebesar Rp2.739 triliun (Tabel 6).

Tabel 6. Perubahan APBN 2020

\begin{tabular}{lccc}
\hline & \multicolumn{3}{c}{ Periode } \\
\cline { 2 - 4 } Jenis & 1 Januari & 3 April & 25 Juni \\
Anggaran & s.d. 2 & s.d. 24 & s.d. 31 \\
& April & Juni 2020 & Desember \\
& 2020 & & 2020 \\
\hline Pendapatan & Rp2.233 & Rp1.760 & Rp1.699 \\
Negara & triliun & triliun & triliun \\
\hline Belanja & Rp2.540 & Rp2.613 & Rp2.739 \\
Negara & triliun & triliun & triliun \\
\hline
\end{tabular}

Sumber: Kementerian Keuangan (2020b)

Perubahan anggaran (APBN) sebagai respon terhadap pandemi Covid-19 meningkatkan defisit APBN. Peningkatan tersebut didorong oleh dua faktor utama. Pertama, situasi pandemi mengakibatkan penurunan aktivitas ekonomi dan pertumbuhan PDB yang minus pada tahun 2020 Kedua, pendapatan negara, khususnya pendapatan perpajakan, mengalami kontraksi seiring dengan siklus perekonomian, sementara belanja pemerintah cenderung membesar untuk membiayai mitigasi, termasuk program PEN.

Guna mengurangi dampak Covid-19, pemerintah telah melakukan tiga kali perubahan anggaran. Setelah diterbitkannya Perpu 1/2020 (tahap pertama), pemerintah menyiapkan anggaran sebesar Rp405 triliun yang rinciannya terdapat dalam perpres 54/2020. Pada tahap kedua, pemerintah menambah anggaran untuk penanganan Covid-19 sebesar Rp677,2 triliun. Pemerintah kembali menambah anggaran penanganan Covid-19 dari Rp677,2 triliun menjadi Rp695,2 triliun.

Fokus penanganan dampak pandemi Covid-19 ditujukan kepada masyarakat, termasuk tenaga kerja di sektor pertanian (Grafik 8). Hal itu terlihat dari alokasi terbesar dalam PEN terdapat pada program perlindungan sosial sebesar Rp203 triliun. Hal utama dalam kebijakan distribusi tersebut adalah adanya dukungan bagi pemberian bantuan tunai dan bantuan bahan pokok. Bantuan kebutuhan bahan pokok merupakan aspek yang mendasar dan pokok dalam program perlindungan sosial.

Sebelum pandemi Covid-19, Pemerintah telah melaksanakan berbagai program perlindungan sosial mencakup pemenuhan hak dasar masyarakat seperti perlindungan kepada kelompok rentan, akses pendidikan dan layanan kesehatan. Program tersebut bertujuan untuk mengurangi dampak negatif terhadap peristiwa/gangguan yang dialami masyarakat agar dapat terlindungi dan hidup lebih layak. Program perlindungan sosial yang sudah berjalan sebelum terjadinya pandemi Covid-19, antara lain:

1) Program Keluarga Harapan (PKH). PKH merupakan pemberian bantuan uang tunai bersyarat (conditional cash transfer) bagi keluarga sangat miskin.

2) Program Indonesia Pintar-Kartu Indonesia Pintar/PIP-KIP. PIP-KIP bantuan tunai pendidikan kepada anak usia sekolah (usia 6 - 21 tahun) dari keluarga miskin/rentan miskin/prioritas.

3) Bantuan Pangan Non-tunai (BPNT) atau Program Beras Sejahtera (Rastra) bagi keluarga yang berada pada kondisi sosial-ekonomi terendah di daerah pelaksanaan.

4) Asistensi Sosial Penyandang Disabilitas (ASPD) yang diberikan kepada penyandang disabilitas berat dan miskin. Besar bantuan untuk setiap PD adalah Rp300.000 per bulan atau senilai Rp3.600.000 per tahun.

Pemerintah telah menerbitkan kebijakan dan program untuk memitigasi dampak Covid-19 terhadap masyarakat. Adapun sejumlah program perlindungan sosial yang diterbitkan pada tanggal 31 Maret 2020 tersebut antara lain (Setkab, 2020): 1) Penambahan alokasi dana pemberian bantuan Program Keluarga Harapan (PKH), 2) Penambahan penerima Kartu Sembako, 3) Penambahan jumlah penerima kartu prakerja, 4) Memberikan program diskon tagihan listrik bagi pengguna 450 VA dan 900 VA, 5) Penambahan alokasi cadangan untuk pengadaan bahan kebutuhan pokok, operasi pasar, dan logistik sebesar Rp25 triliun, 6) Pemberian bantuan pembayaran kredit bagi pekerja informal.

Instruksi Presiden Nomor 4/2020 mengatur tambahan anggaran bagi program perlindungan sosial dan penanggulangan dampak pandemi terhadap perekonomian nasional. Adapun alokasi anggaran penanganan dampak Covid-19 sebesar Rp695,2 triliun. Jumlah tersebut terdiri dari anggaran untuk bidang kesehatan sebesar Rp97,9 triliun dan anggaran untuk Pemulihan Ekonomi Nasional (PEN) sebesar Rp597,3 triliun. Adapun anggaran PEN digunakan untuk mendorong sisi penawaran (supply side) sebesar Rp297,6 triliun dan mendukung sisi permintaan (demand side) sebesar Rp299,7 triliun (Kementerian Keuangan, diakses 14 Desember 2020c).

Hasil survei Mei 2020 sampai Agustus 2020 menyebutkan bahwa 90 persen target penerima manfaat telah menerima sejumlah program bantuan. Program perlindungan sosial yang menjadi cakupan survei meliputi $\mathrm{PKH}$, kartu 
sembako, Bantuan Sembako Jabodetabek dan BLT non Jabodetabek, BLT Dana Desa, Subsidi Listrik, Kartu Prakerja dan program Padat Karya (www.covid19.go.id, 2020).

Grafik 8. Penerima Manfaat Program Bantuan Sosial Berdasarkan Lapangan Usaha

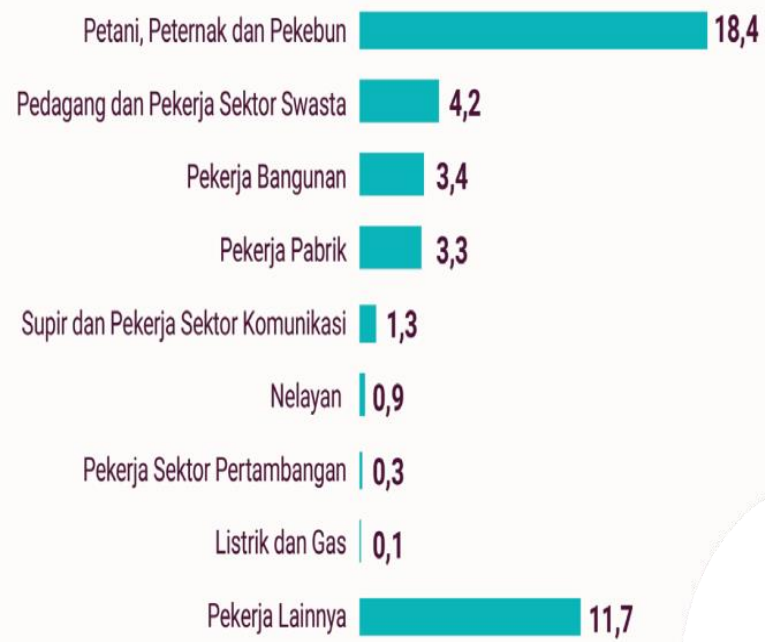

Sumber: Kementerian Keuangan (2020c)

Penerbitan kartu prakerja dilandasi oleh Perpres 36/2020 pada tanggal 28 Februari 2020. Program tersebut bertujuan untuk memitigasi terjadinya pengangguran dan kemiskinan pada saat pandemi. Penerima kartu prakerja mencakup masyarakat yang tidak bekerja dan dirumahkan saat Covid-19. Keberadaan program kartu prakerja diharapkan dapat memotivasi masyarakat untuk meningkatkan keterampilan/keahlian melalui pelatihan yang tersedia. Selanjutnya, masyarakat dapat memanfaatkan keterampilan dan keahliannya untuk meningkatkan bekerja/meningkatkan produktivitas sesuai kompetensi yang dimiliki.

Program kartu prakerja dapat didesain untuk mendukung peningkatan produktivitas tenaga kerja sektor pertanian. Mengingat produktivitas tenaga kerja sektor pertanian relatif rendah, program kartu prakerja perlu disusun dalam kerangka peningkatan investasi sumber daya manusia (SDM). Investasi tersebut bertujuan menghasilkan SDM sektor pertanian yang berkualitas, memiliki kompetensi dan daya saing. Investasi sumber daya manusia sektor pertanian dilakukan melalui:

1) Peningkatan akses/kesempatan dan mutu pelatihan berbasis kompetensi yang inklusif atau tidak mensyaratkan (batasan) usia maupun latar belakang.

2) Mempersiapkan sumber daya manusia sektor pertanian yang siap memasuki era teknologi dan digital.

3) Melaksanakan reorientasi, revitalisasi, dan rebranding melalui program kartu prakerja dengan tujuan untuk mempercepat ketersediaan SDM sektor pertanian yang kompeten.

Salah satu pelaksanaan program kartu prakerja di sektor pertanian adalah pelatihan di bidang peternakan. Seluruh Unit Pelaksana Teknis (UPT) dalam lingkup Badan Penyuluhan dan Pengembangan Sumber Daya Manusia Pertanian (BPPSDMP Kementerian Pertanian) berperan sebagai tempat pelatihan. Pelatihan tersebut dapat diikuti oleh pemegang kartu prakerja yang berusia lebih dari 18 tahun, dan tidak sedang menempuh pendidikan formal dengan melakukan akses dalam laman Sisnaker (Bbppbatu, 2020).

Program kartu prakerja dipandang sebagai insentif pelatihan. Komitmen masyarakat untuk berpartisipasi dalam program pelatihan diperlukan agar terjadi peningkatan keterampilan dan keahlian, termasuk untuk pengembangan sektor pertanian. Kesiapan sumber daya manusia sektor pertanian dalam menyongsong tantangan ekonomi di masa depan membantu pemulihan ekonomi secara lebih cepat.

Program Kartu Prakerja merupakan program unggulan Pemerintah pada periode 2019-2024. Program Kartu Prakerja adalah bantuan biaya pelatihan guna mengembangkan kompetensi, meningkatkan produktivitas dan daya saing. Kartu Prakerja mencakup semua penduduk yang berusia minimal 18 tahun dan tidak sedang menjalankan pendidikan formal, termasuk buruh, karyawan dan pegawai serta angkatan kerja yang sedang mencari pekerjaan.

Kartu Prakerja dapat membekali sumber daya manusia sektor pertanian dengan program pelatihan yang dapat meningkatkan kompetensi angkatan kerja, termasuk pelaku sektor pertanian. Adapun materi pembelajaran yang dapat mendukung sektor pertanian, antara lain: tutorial keterampilan panen, pemanfaatan teknologi digital, informasi dan tutorial terkait sarana dan prasarana pertanian serta keterampilan penggunaan teknologi modern. Di samping itu, diperlukan perbaikan kesejahteraan petani secara konsisten. Selama kesejahteraan petani kurang memadai, sektor pertanian akan sulit meningkatkan kontribusinya pada perekonomian.

Implementasi kartu prakerja masih menghadapi kendala, seperti keterbatasan infrastruktur terkait ketersediaan teknologi di daerah. Namun, program kartu prakerja diharapkan dapat menjadi salah satu sarana mitigasi dari dampak negatif pandemi Covid-19. Berkaitan dengan produktivitas sektor pertanian pada masa pandemi, petani dapat memperoleh keahlian/keterampilan yang digunakan untuk berwirausaha atau meningkatkan efektivitas dan 
efisiensi terkait proses produksi pertanian dan akses pemasaran.

$\begin{array}{rrrr}\begin{array}{c}\text { Data } \\ \text { pelatihan }\end{array} & \text { BPS } & \begin{array}{c}\text { menyebutkan } \\ \text { daring }\end{array} \text { dari program } & \text { prakerja }\end{array}$
meningkatkan produktivitas. Sejak Januari 2020 hingga April 2020, peserta pelatihan yang telah menerima pelatihan terlibat dalam aktivitas produktif dari rumah dengan membuka usaha secara daring/online. Adapun program prakerja yang telah mencakup sektor pertanian masih berkaitan dengan peningkatan keahlian dalam peternakan, pelatihan wirausaha tani padi dan jagung. Program pelatihan kategori pertanian termasuk salah satu kategori pelatihan yang banyak diakses oleh peserta kartu prakerja.

Realokasi anggaran pertanian melalui pengalihan beberapa pos anggaran kartu prakerja untuk intensifikasi pertanian dapat meningkatkan penyerapan tenaga kerja, mendukung penyaluran bantuan, serta menjaga ketersediaan pangan di masyarakat. Berkaitan dengan pengembangan sumber daya manusia sektor pertanian, diperlukan adanya platform sebagai mitra penyelenggara pelatihan yang dapat memberikan materi terkait pertanian (Siregar dan Oktaviana, 2020).

Salah satu implementasi kebijakan kartu prakerja dapat digunakan untuk melakukan pelatihan untuk meningkatkan keterampilan petani dalam memanen kelapa sawit dan coklat dengan praktik yang ramah lingkungan. Petani yang belum memiliki pengetahuan dan keterampilan dapat diberikan pelatihan. Selain itu, program kartu prakerja pertanian dapat digunakan untuk pelatihan petani padi dan sayur/buah/bunga organik agar memiliki pengetahuan mengenai praktik pertanian berkelanjutan. Petani yang menguasai keahlian tersebut pendapatannya akan meningkat karena harga produk organik jauh lebih tinggi. Upaya tersebut diharapkan dapat menjaga pertumbuhan positif sektor pertanian sehingga memberikan kontribusi terhadap ekonomi nasional melalui produksi pangan yang tetap terjaga.

Program kartu prakerja menjadi penting sebagai upaya diseminasi informasi teknologi pertanian yang dapat menunjang pengetahuan, ketrampilan teknis, ketrampilan manajerial bagi sumber daya manusia di sektor pertanian. Tenaga kerja sektor pertanian penting untuk tetap didukung oleh pemerintah daerah dan pemerintah pusat melalui pengembangan kapasitas sumber daya manusia. Pengembangan sumber daya manusia sektor pertanian tetap diperlukan, baik pada saat maupun setelah pandemi Covid-19.

Terdapat pemberian bantuan bagi petani dan nelayan dalam program PEN 2020. Insentif tersebut mencakup 3,8 juta petani dan nelayan masuk dalam daftar penerima bantuan yang dapat digunakan untuk meningkatkan usaha pertanian dan perikanan. Bantuan tersebut mencakup (Sekretariat Negara, 2020):

1) Program bantuan sosial berupa Keluarga Harapan (PKH), Bantuan Sosial Tunai, Bantuan Langsung Tunai Desa, paket sembako, dan program subsidi listrik;

2) Bantuan relaksasi pembayaran angsuran dan pemberian subsidi bunga kredit yang disalurkan lewat Kredit Usaha Rakyat (KUR), Membina Keluarga Sejahtera (Mekaar), pembiayaan ultramikro (UMi), pegadaian, dan perusahaan pembiayaan lainnya sebesar Rp34 triliun;

3) Kemudahan prosedur dan akses pemberian stimulus untuk modal kerja;

4) Instrumen bantuan non fiskal dan kebijakan kelancaran supply chain berupa ketersediaan bibit, pupuk, dan alat-alat produksi.

Pelaksanaan pemberian bantuan bagi petani dan nelayan dalam program PEN 2020 antara lain: 1) penyaluran KUR bagi petani dan pembudidaya ikan oleh 6 lembaga penyalur KUR (BRI Syariah, BNI Syariah, BJB, Bank Mandiri, BNI, dan BRI), 2) pemberian bantuan Kementerian Pertanian seperti bantuan benih sayuran kepada kelompok tani, bantuan bibit padi, jagung, dan kedelai, serta bantuan sarana-prasarana pengembangan perbenihan kentang, 3) penyerahan bantuan oleh Kementerian Kelautan dan Perikanan berupa paket benih dan pakan ikan nila kepada kelompok nelayan, serta 4) pemberian bantuan oleh Kementerian Koperasi dan UKM berupa hibah produktif kepada 100 calon penerima masingmasing sebanyak Rp2,4 juta (Setyowati, 2020).

Program perlindungan sosial dapat menjaga kesejahteraan petani untuk tetap berproduksi selama masa pandemi Covid-19. Salah satu solusi yang dapat ditempuh dalam jangka pendek adalah perluasan pemberian BLT. Dalam jangka panjang, implementasi program Kartu Prakerja perlu ditingkatkan. Hal ini untuk mendukung peningkatan kualitas dan keterampilan masyarakat, khususnya untuk pengembangan sektor pertanian. Berbagai upaya yang dilakukan yang dilakukan tersebut turut mendukung pertumbuhan sektor pertanian pada masa pandemi Covid-19.

Investasi ke sektor pertanian diperlukan untuk menjaga dan mendorong pertumbuhan sektor pertanian. Asian Development Bank mencatat investasi asing di sektor pertanian Indonesia hanya menyumbang kurang dari lima persen. Di sisi lain, keberadaan sumber daya manusia yang berkualitas menjadi faktor yang dipertimbangkan dalam keputusan investasi. Oleh karena itu, strategi pengembangan kapasitas sumber daya manusia 
sektor pertanian di tengah pandemi Covid-19 dilakukan melalui:

1) Program pemberdayaan petani dan padat karya. Program padat karya tersebut diarahkan pada perbaikan / peningkatan fungsi sarana dan prasarana pertanian sehingga dapat mendukung proses produksi dan distribusi komoditas pertanian.

2) Ketersediaan dan akses pangan dengan harga terjangkau. Akses pangan mendukung terpenuhinya gizi yang dapat meningkatkan daya tahan dan kesehatan tenaga kerja sektor pertanian sehingga mampu bekerja untuk menghasilkan produk pertanian.

Pada saat wabah Covid-19, pengembangan pasar bagi produk pertanian dilakukan melalui pemberian bantuan permodalan untuk proses produksi, peningkatan keterampilan tenaga kerja, dan pelibatan generasi muda. Pemahaman yang menyeluruh tentang perubahan perilaku melalui penyebaran informasi tentang pentingnya multi channel marketing dan promosi kesehatan untuk menerapkan pola hidup sehat serta makanan sehat dapat membantu masyarakat dalam situasi pandemi. Di samping itu, kebijakan yang disusun didukung oleh pengembangan teknik pemasaran pertanian yang meningkatkan keterkaitan antara petani dan konsumen. Dalam jangka panjang, informasi yang komprehensif mencakup pemahaman masyarakat terhadap urgensi perubahan perilaku yang mendukung kesejahteraan petani melalui sinergi dan akselerasi penguatan strategi modernisasi pertanian berkelanjutan.

\section{KESIMPULAN DAN SARAN}

Berdasarkan uraian yang telah dijelaskan, dapat disimpulkan bahwa pandemi Covid-19 yang semakin meluas berdampak negatif pada produktivitas tenaga kerja sektor pertanian. Pandemi tersebut meningkatkan risiko kesehatan bagi masyarakat dan tenaga kerja sektor pertanian sehingga mengurangi kegiatan/bekerja dan dapat mengganggu produksi pertanian. Pembatasan sosial dapat mengganggu proses memperoleh input pertanian hingga pemasaran output/produk pertanian. Di samping itu, pandemi Covid-19 meningkatkan beban pengeluaran terkait perlindungan kesehatan dan menimbulkan kerugian pendapatan tenaga kerja sektor pertanian. Penurunan pendapatan menimbulkan ancaman kemiskinan, penurunan status kesehatan dan hambatan pendidikan yang merugikan produktivitas tenaga kerja sektor pertanian. Program PEN mendukung produktivitas tenaga kerja sektor pertanian melalui pemberian bantuan dan pengembangan kapasitas tenaga kerja sektor pertanian menggunakan alokasi bantuan sosial (bansos), penyaluran $\mathrm{PKH}$, dan tambahan kartu prakerja. Bantuan sosial dan program pengembangan kapasitas tenaga kerja sektor pertanian tersebut meringankan beban dan memungkinkan tenaga kerja sektor pertanian tetap bekerja dan produktif sehingga dapat mendukung perkembangan sektor pertanian yang berkelanjutan.

Guna mempertahankan dan meningkatkan produktivitas tenaga kerja sektor pertanian, program PEN dapat diperluas untuk untuk pengembangan sumber daya manusia sektor pertanian melalui pendidikan dan pelatihan berkualitas secara daring yang mengedepankan inovasi, penguatan keterampilan yang dapat beradaptasi dengan kemajuan teknologi, pengembangan kewirausahaan. Pengembangan sumber daya manusia sektor pertanian perlu diberikan kepada tenaga kerja muda dan tenaga kerja lanjut usia dan difokuskan pada teknis pertanian untuk mendukung praktik pertanian yang berkelanjutan, pemanfaatan teknologi pertanian, termasuk digitalisasi dalam memperoleh input hingga pemasaran output/produk pertanian.

\section{PENGHARGAAN}

Penulis mengucapkan terima kasih kepada para reviewer yang telah memberikan komentar dan masukan untuk perbaikan artikel ini. Penulis mengucapkan terima kasih kepada Bapak Hidayat Amir, Ph.D., Kepala Pusat Kebijakan Ekonomi Makro, yang telah memberikan masukan dan mendukung penyelesaian penelitian ini. Peneliti mengucapkan terima kasih kepada Bapak Riznaldi Akbar, Ph.D., Bapak Yoopi Abimanyu, Ph.D., Bapak Rudi Handoko, Bapak R. Nurhidajat, Bapak Dr. Cornelius Tjahjaprijadi, Bapak Yusuf Munandar, dan Ibu Nugraheni Kusumaningsih atas kesempatan berdiskusi terkait penelitian ini.

Tulisan ini merupakan tanggung jawab pribadi dan tidak mencerminkan instansi tempat penulis bekerja.

\section{REFERENSI}

Abast, D. E. H. U., Moniaga, I. L., \& Gosal, P. H. (2020). Tingkat Kerentanan Terhadap Bahaya Banjir di Kelurahan Ranotana. Jurnal Spasial, 3(2), 123130

Abidin, M. Z. (2015). Dampak Kebijakan Impor Beras dan Ketahanan Pangan Dalam Perspektif Kesejahteraan Sosial. Jurnal Sosio Informa, 1(3), 213-230

Adam, L. (2016). Membangun Daya Saing Tenaga Kerja Indonesia Melalui Peningkatan Produktivitas. Jurnal Kependudukan Indonesia 11(2), 71-84 
Ansell, Nicola, Flora H., Lorraine V. B., \& Elsbeth, R. (2016). AIDS-affected young people's access to livelihood assets: Exploring 'new variant famine' in rural southern Africa. Journal of Rural Studies, 46(23-34).

Arifin, B. (2004). Analisis Ekonomi Pertanian Indonesia. Jakarta: Penerbit Kompas.

Arouri, M., Cuong N., \& Adel B. Y. (2015). Natural Disasters, Household Welfare, and Resilience: Evidence from Rural Vietnam. World Development, 70, 59-77

Ashraf, B. N. (2020) Economic impact of government interventions during the COVID19 pandemic: International evidence from financial markets. Journal of Behavioral and Experimental Finance, 27,

Asrul, I., \& Ismail, N. (2014). Identifikasi Kerentanan Lingkungan dan Kerentanan Ekonomi Wilayah dari Risiko Bencana Banjir Rob di Kecamatan Baitusaalam Kabupaten Aceh Besar. Jurnal Ilmu Kebencanaan, 1(2), 47-54

Badan Pusat Statistik. (2018). Analisis Sosial Ekonomi Petani di Indonesia Hasil Survei Pendapatan Rumah Tangga Usaha Pertanian Sensus Pertanian 2013. Jakarta: Badan Pusat Statistik.

Badan Pusat Statistik. (2018). Hasil Survei Pertanian Antar Sensus (SUTAS) 2018. Jakarta: Badan Pusat Statistik.

Badan Pusat Statistik. (2020a). Keadaan Ketenagakerjaan Indonesia Februari. Berita Resmi Statistik No. 40/05/Th.XXIII, 5 Mei. Jakarta: Badan Pusat Statistik.

Badan Pusat Statistik. (2020b). Hasil Survei Sosial Demografi Dampak Covid-19 tahun 2020. Jakarta: Badan Pusat Statistik.

Badan Pusat Statistik. (2020c). Keadaan Ketenagakerjaan Indonesia Agustus 2020. Berita Resmi Statistik No.86/11/Th. XXIII, 05 November 2020. Jakarta: Badan Pusat Statistik.

Badan Pusat Statistik. (2020d). Pertumbuhan Ekonomi Indonesia Triwulan IV-2020. Berita Resmi Statistik No. 13/02/Th. XXIV, 5 Februari 2021. Jakarta: Badan Pusat Statistik.

Badan Pusat Statistik. (2021a). Laju Pertumbuhan PDB Seri 2010. Retrieved from the Badan Pusat Statistik website Https://www.bps.go.id/indicator/11/104/5/ -seri-2010-laju-pertumbuhan-pdb-seri2010.html, diakses 13 Februari 2021.

Badan Pusat Statistik. (2021b). Perkembangan Indeks Harga Konsumen/Inflasi. Berita Resmi
Statistik No. 01/01/Th.XXIV, 4 Januari. Jakarta: Badan Pusat Statistik.

Balwinder-S., Paresh B. S., Jat M.L., McDonald A.J., Amit K. S., Peter C., Rana D.S., Singh A.K., Chaudhari S.K., Sharma P.C., Rajbir S., Jat H.S., Sidhu H.S., Gerard B., Hans B. (2020). Agricultural Labor, Covid-19, and Potential Implications for Food Security and Air Quality in The Breadbasket of India. Agricultural Systems, 185, 102954.

Bbppbatu. (2020). Berlatih Peternakan Dengan Kartu Prakerja. Retrieved from the BBPP Batu website:

https://bbppbatu.bppsdmp.pertanian.go.id/2 020/06/24/berlatih-peternakan-dengankartu-prakerja/

Bochtis, D., Benos, L., Lampridi, M., Marinoudi, V., Pearson, S., Sørensen, C.G. (2020). Agricultural Workforce Crisis in Light of the COVID-19 Pandemic. Sustainability, 12, 8212.

Chakraborty, Indranil, \& Prasenjit M. (2020). COVID-19 outbreak: Migration, effects on society, global environment and prevention. Science of The Total Environment, 728.

Chansarn, S. (2010). Labor Productivity Growth, Education, Health and Technological Progress: A Cross-Country Analysis. Economic Analysis and Policy, 40(2), 249-261

Cinnirella, F., \& Streb, J. (2017). The Role of Human Capital And Innovation In Economic Development: Evidence From Post-Malthusian Prussia. J Econ Growth, 22, 193-227.

Cortignani, R., Carulli, G., \& Dono, G. (2020). COVID19 and Labour in Agriculture: Economic and Productive Impacts in An Agricultural Area of The Mediterranean. Italian Journal of Agronomy, 15(2), 172-181,

Dahiri \& Fitri, H. (2020). Sektor Pertanian: Berperan Besar, Realisasi Investasi Belum Optimal. Buletin APBN V(14), 7.

Damanhouri, Amal M. S. \& Divya R. (2017). Factors Influencing Labour Productivity-An Applied Study of Non Oil Manufacturing Sectors in The Kingdom of Saudi Arabia. Global Journal of Commerce \& Management Perpective, 6(6), 6071

Danuwikarsa, I. (2013). Peran Perguruan Tinggi Melalui Penelitian dan Program Pengabdian Kepada Masyarakat Dalam Penanggulangan Bencana di Indonesia. Jurnal Pengabdian Masyarakat 3(1), 1-14

De Silva, M.M.G.T., \& Akiyuki K. (2018). Socioeconomic Vulnerability to Disaster Risk: A Case Study of Flood and Drought Impact in a 
Rural Sri Lankan Community. Ecological Economics, 152, 131-140.

Erokhin, V., \& Gao, T. (2020). Impacts of COVID-19 on Trade and Economic Aspects of Food Security: Evidence from 45 Developing Countries. International Journal of Environmental Research and Public Health, 17(16), 5775

Farah, A., \& Sari, E. P. (2014). Modal Manusia dan Produktivitas. JEJAK Journal of Economics and Policy, 7 (1), 22-28

Faturahman, \& Burhanudin, M. (2018). Konseptualisasi Mitigasi Bencana Melalui Perspektif Kebijakan Publik. Jurnal Ilmu Administrasi Publik: Publisia, 3(2), 122-134

Febrianto, V. (2021). Masalah Klasik Kian Menjerat Petani Saat Pandemi Covid-19. Retrieved from Kantor Berita Antara website: https://www.antaranews.com/berita/19444 96/masalah-klasik-kian-menjerat-petani-saatpandemi-covid-19

Fry-Bowers, E. K. (2020). Children are at Risk from COVID-19. Journal of pediatric nursing,53( A10-A12)

Gatiso, T. T., Ordaz-Németh, I., Grimes, T., Lormie, M., Tweh, C., Kühl, H.S., et al. (2018). The impact of the Ebola virus disease (EVD) epidemic on agricultural production and livelihoods in Liberia. PLoS Negl Trop Dis 12(8), e6580.

Gregorioa, G. B. \& Ancog, R. C. (2020). Assessing the Impact of the COVID-19 Pandemic on Agricultural Production in Southeast Asia: Toward Transformative Change in Agricultural Food Systems. Asian Journal of Agriculture and Development, Southeast Asian Regional Center for Graduate Study and Research in Agriculture (SEARCA), 17(1)

Jovovic, R., Draskovic, M., Delibasic, M., \& Jovovic, M. (2017). The Concept Of Sustainable Regional Development - Institutional Aspects, Policies And Prospects. Journal of International Studies, 10(1), 255-266.

Kementerian Keuangan. (2020a). Media Briefing: Program Pemulihan Ekonomi Nasional. Retrieved from the Kementerian Keuangan RI website:

https://www.kemenkeu.go.id/media/15116/ media-briefing-kabkf.pdf

Kementerian Keuangan. (2020b). Program PEN. Retrieved from the Kementerian Keuangan RI website: https://www.kemenkeu.go.id/media/15365/ photostory_pen.pdf
Kementerian Keuangan. (2020c). Kemenkeu Tanggap Covid-19: Informasi Terkini. Retrieved from the Kementerian Keuangan RI website: https://www.kemenkeu.go.id/media/14830/ refocusing-realokasi-covid19_1.png

Kementerian Pertanian. (2020). Kebijakan Kementerian Pertanian Merespons Covid-19: Tetap Menjaga Ketersediaan Pangan Bagi Seluruh Rakyat Indonesia. Retrieved from the Kementerian Pertanian RI website: http://pse.litbang.pertanian.go.id/ind/index.p hp/covid-19/program-kegiatan/333kebijakan-kementerian-pertanian-meresponscovid-19-tetap-menjaga-ketersediaanpangan-bagi-seluruh-rakyat-indonesia

Kementerian Pertanian. (2020a). Statistik Ketenagakerjaan Sektor Pertanian Tahun 2019 - Februari 2020. Jakarta: Pusat Data dan Sistem Informasi Pertanian, Sekretariat Jenderal.

Knapp, D. (2007). The Influence of Health on Labor Productivity: An Analysis of European Conscription Data. A Senior Honor Thesis, Department of Economics, Ohio State University.

Lal, Preet, Amit, K., Shubham, K., Sheetal, K., Purabi, S., Arun, D., Dibyendu, A., \& Khan, M.L. (2020). The dark cloud with a silver lining: Assessing the impact of the SARS COVID-19 pandemic on the global environment. Science of The Total Environment, 732.

Lucas, B. (2020). Impacts of Covid-19 on Inclusive Economic Growth in Middle-income Countries. K4D Helpdesk Report 811. Brighton: Institute of Development Studies.

Mikolai, Júlia, Katherine K., \& Hill, K. (2020). Intersecting household-level health and socioeconomic vulnerabilities and the COVID-19 crisis: An analysis from the UK, SSM - Population Health, 12.

Mononimbar, W. J. (2019). Flood Disaster Mitigation Concept of Settlements in Sario Watershed Area. Journal of Sustainable Engineering: Proceedings Series 2019 - The 2nd International Conference on Sustainable Engineering Practices (IConSEP 2019), 1(2) https://doi:10.35793/joseps.v1i2

Morganstein, J. C., \& Ursano, R. J. (2020). Ecological Disasters and Mental Health: Causes, Consequences, and Interventions. Front. Psychiatry 11(1)

Mphande, F. A. (2016). Infectious Diseases and Rural Livelihoods in Developing Countries. Singapore: Springer. 
Mukiibi, E. (2020). COVID-19 and the state of food security in Africa. Agric Hum, 37, 627-628.

Munawar, H. S., Qayyum, S., Ullah, F., Sepasgozar, S. (2020). Big Data and Its Applications in Smart Real Estate and the Disaster Management Life Cycle: A Systematic Analysis. Big Data Cogn. Comput, 4(2), 4.

Ngadi. (2020). Survei Dampak Darurat Virus Corona terhadap Tenaga Kerja Indonesia. Retrieved from the LIPI website: http://lipi.go.id/siaranpress/survei-dampakdarurat-virus-corona-terhadap--tenaga-kerjaindonesia/22030. Diakses 23 Oktober 2020.

Nicola, Maria, Zaid, A., Catrin, S., Ahmed, K., Ahmed, A-J., Christos, I., M, Agha., R, Agha. (2020). The socio-economic implications of the coronavirus pandemic (COVID-19): A review, International Journal of Surgery, 78, 185-193, https://doi.org/10.1016/j.ijsu.2020.04.018

Noy, I., \& Rio, Y. (2018). Economic Vulnerability and Resilience to Natural Hazards: A Survey of Concepts and Measurements. Sustainability, 10 (8), 2850

Ozili, P. K., \& Arun, T. (2020). Spillover of Covid-19: impact on the Global Economy. Retrieved from DOI Foundation website: http://dx.doi.org/102139/ssrn.3562570.

Puspasari, R. (2020). Perkembangan Ekonomi dan Refocusing Anggaran untuk Penanganan Covid19 di Indonesia. Retrieved from the Kementerian Keuangan RI website https://www.kemenkeu.go.id/publikasi/siara n-pers/siaran-pers-perkembangan-ekonomidan-refocusing-anggaran-untuk-penanganancovid-19-di-indonesia

Qarnain, S. S., Muthuvel, S., \& Muthuvel, S. (2020). Review on government action plans to reduce energy consumption in buildings amid COVID19 pandemic outbreak, Materials Today: Proceedings, Retrieved from DOI Foundation website:

https://doi.org/10.1016/j.matpr.2020.04.723

Richard, B. M., Ellen, O. A., \& Frederick, K. (2018). Education and Training of Small-Scale Entrepreneurs: A Tool for Poverty Reduction in the Nkoranza South Municipality, Ghana. Journal of Business and Management Sciences, 6(4), 143-151.

https://doi: 10.12691/jbms-6-4-2

Rivera, M. G., \& Howden-Chapman, P. (2020). Structural Adjustment and Community Resilience: The Case of Postdisaster Housing Recovery After the Canterbury Earthquakes of 2010 and 2011. Health Education \& Behavior, 47(6), 805-815.
Rohmani, S. A. (2020). Implikasi Covid-19 Bagi Upaya Pemenuhan Kebutuhan Pangan. Buletin Perencanaan Pembangunan Pertanian, 1(2), 41-55.

Rusdiana, S. \& Chalid, T. (2020). National Strategy and Policy on The Agricultural Sector During The Covid-19 Outbreak. SOCA: Jurnal Sosial Ekonomi Pertanian, 14(3), 572-590. https://doi.org/10.24843/SOCA.2020.v14.i03 .p17

Saliola, F., Mohamed, I., Asif, Winker, Hernan. (2020). Adapting Jobs Policies and Programs in the Face of Accelerated Technological Change.Jobs Notes; No. 8. World Bank, Washington, DC. (C) World Bank. Retrieved from World Bank website: https://openknowledge.worldbank.org/handl e/10986/33695.

Satgas Covid-19. (2020). Modal Pemulihan Ekonomi. Retrieved from the Satgas Covid-19 website: https://covid19.go.id/p/berita/modalpemulihan-ekonomi-2021. Modal Pemulihan Ekonomi 2021, diakses 25 Oktober 2020.

Sauda, R.H., Nugraha, A. L., \& Hani'ah. (2019). Kajian Pemetaan Kerentanan Banjir Rob di Kabupaten Pekalongan. Jurnal Geodesi Undip, 8 (1), 466-474

Sekretariat Kabinet. (2021). BPS: Sektor Pertanian Tumbuh Positif 2,59 Persen di Kuartal ke IV. Retrieved from the Sekretariat Kabinet RI website: https://setkab.go.id/bps-sektorpertanian-tumbuh-positif-259-persen-dikuartal-ke-iv/https://setkab.go.id/bpssektor-pertanian-tumbuh-positif-259-persendi-kuartal-ke-iv/, diakses 17 Maret 2021.

Sekretariat Negara. (2020). Empat Skema Insentif bagi Petani dan Nelayan untuk Jaga Ketersediaan Bahan Pokok. Retrieved from the Kementerian Sekretariat Negara RI website: https://setneg.go.id/baca/index/empat_skem a_insentif_bagi_petani_dan_nelayan_untuk_jag a_ketersediaan_bahan_pokok

Setyowati, H. E. (2020). Pemerintah Sinergikan Program Pemberdayaan SHAT dengan Penyaluran KUR. Retrieved from the Ekon website:

https://www.ekon.go.id/publikasi/detail/567 /pemerintah-sinergikan-programpemberdayaan-shat-dengan-penyaluran-kur, diakses 28 November 2020.

Sina, D., Alice, Y. C. R., Suzanne, W., \& Regan, P. (2019). What Does The Future Hold for Relocated Communities Post-Disaster? Factors Affecting Livelihood Resilience. International Journal of Disaster Risk Reduction, 34, 173-183. https://doi.org/10.1016/j.ijdrr.2018.11.015. 
Siregar, A. P. \& Nadia, O. (2020). Realokasi Kartu Pra Kerja Dalam Mendukung Intensifikasi Sektor Pertanian. Agrisaintifika Jurnal Ilmu-Ilmu Pertanian 4(1), 1-13

Sohrabi, Catrin, Zaid, A., Niamh, O'Neill., Mehdi, K., Ahmed, K., Ahmed, Al-Jabir, Christos, I., \& Riaz, A. (2020). World Health Organization declares global emergency: A review of the 2019 novel coronavirus (COVID-19). International Journal of Surgery, 76, 71-76. https://doi.org/10.1016/j.ijsu.2020.02.034

Swinnen, J. \& McDermott, J. (2020), Covid-19 and Global Food Security. Retrieved from DOI Foundation website:. https://doi.org/10.1111/1746692X.12288.

Thow, A. M., Sharma, S. K. \& Rachmi, C. N. (2019). An analysis of Indonesia's shrinking food security policy space under the WTO. Food, 11, 12751287.

Ubaidillah, A. (2018). Pemulihan Ekonomi Pasca Bencana Banjir Melalui Usaha Kerajinan Tas Limbah Plastik Bagi Petani di Dusun Koryo Desa Bulutigo Kecamatan Laren Kabupaten Lamongan. Skripsi, Universitas Islam Negeri Sunan Ampel Surabaya.

Utomo, S. J. \& Baskoro, H. A. (2019). Productivity of Indonesia Agriculture: Study in ASEAN State. Jurnal Ilmu Ekonomi dan Pembangunan, 19(2), 104

Wang, J., Wei, S., J, K. (2020). Analysis of the impact of COVID-19 on the correlations between crude oil and agricultural futures, Chaos, Solitons \& Fractals, Volume 136, Retrieved from DOI Foundation website: https://doi.org/10.1016/j.chaos.2020.109896

Webb, A., Gary, R., Kathleen, J. T., \& James, M. D. (2002). Predicting long-term business recovery from disaster: a comparison of the Loma Prieta earthquake and Hurricane Andrew, Global Environmental Change Part B: Environmental Hazards, 4(2), 45-58.

Widyastuti, A., (2012). Analisis Hubungan Antara Produktivitas Pekerja Dan Tingkat Pendidikan Pekerja Terhadap Kesejahteraan Keluarga Di Jawa Tengah Tahun 2009. Economics Development Analysis Journal, 1(2). https://doi.org/10.15294/edaj.v1i2 